NBER WORKING PAPER SERIES

\title{
MACROECONOMIC CONDITIONS AND CAPITAL RAISING
}

\author{
Isil Erel \\ Brandon Julio \\ Woojin Kim \\ Michael S. Weisbach \\ Working Paper 16941 \\ http://www.nber.org/papers/w16941
}

\author{
NATIONAL BUREAU OF ECONOMIC RESEARCH \\ 1050 Massachusetts Avenue \\ Cambridge, MA 02138 \\ April 2011
}

We would like to thank Effi Benmelech, Murillo Campello, Naveen Daniel, Mike Faulkender, John Graham, Campbell Harvey, Christopher Hennessy, Mark Huson, Mike Lemmon, Laura Liu, Gordon Phillips, Matt Spiegel, Per Stromberg, René Stulz, Ralph Walkling, and an anonymous referee, as well as seminar participants at The 2009 AFA Meetings, University of Alberta, Carnegie Mellon University, University of Cincinnati, Drexel University, Harvard University, Hong Kong University of Science and Technology, KDI School of Public Policy and Management, Korea University, University of Illinois, NBER, Ohio State University, Oxford University, Seoul National University, Southern Methodist University, Stockholm School of Economics, University of Utah, Washington University, and Yale University for very helpful suggestions. The views expressed herein are those of the authors and do not necessarily reflect the views of the National Bureau of Economic Research.

NBER working papers are circulated for discussion and comment purposes. They have not been peerreviewed or been subject to the review by the NBER Board of Directors that accompanies official NBER publications.

(C) 2011 by Isil Erel, Brandon Julio, Woojin Kim, and Michael S. Weisbach. All rights reserved. Short sections of text, not to exceed two paragraphs, may be quoted without explicit permission provided that full credit, including (C) notice, is given to the source. 
Macroeconomic Conditions and Capital Raising

Isil Erel, Brandon Julio, Woojin Kim, and Michael S. Weisbach

NBER Working Paper No. 16941

April 2011

JEL No. E00,G21,G32

\begin{abstract}
$\underline{\text { ABSTRACT }}$
Do macroeconomic conditions affect firms' abilities to raise capital? If so, how do they affect the manner in which the capital is raised? We address these questions using a large sample of publicly-traded debt issues, seasoned equity offers, bank loans and private placements of equity and debt. Our results suggest that a borrower's credit quality significantly affects its ability to raise capital during macroeconomic downturns. For noninvestment-grade borrowers, capital raising tends to be procyclical while for investment-grade borrowers, it is countercyclical. Moreover, proceeds raised by investment grade firms are more likely to be held in cash in recessions than in expansions. Poor market conditions also affect the structure of securities offered, shifting them towards shorter maturities and more security. Overall, our results suggest that macroeconomic conditions influence the securities that firms issue to raise capital, the way in which these securities are structured and indeed firms' ability to raise capital at all. This influence likely occurs primarily through the effect of macroeconomic conditions on the supply of capital.
\end{abstract}

Isil Erel

Department of Finance

Ohio State University

832 Fisher Hall

2100 Neil Avenue

Columbus, OH 43210

erel@fisher.osu.edu

Brandon Julio

London Business School

Regent's Park

London NW1 4SA

United Kingdom

bjulio@london.edu
Woojin Kim

Korea University Business School

Anam-Dong, Seongbuk-Gu,

Seoul 136-701

South Korea

woojinkim@korea.ac.kr

Michael S. Weisbach

Department of Finance

Fisher College of Business

Ohio State University

2100 Neil Ave.

Columbus, $\mathrm{OH} 43210$

and NBER

weisbach.2@osu.edu 


\section{Introduction}

Practitioners view the possibility that macroeconomic conditions will adversely affect a firm’s access to capital markets as an important factor in their firms' financial policies. For example, Richard Passov, the longtime treasurer of Pfizer, argues that the possibility of being shut out of the capital markets during market downturns is the primary reason why Pfizer and other technology companies often place such importance on a high bond rating (See Passov 2003). According to Graham and Harvey (2001)'s well-known survey, an important goal of Chief Financial Officers is to maintain financial flexibility "so that they do not need to shrink their business in case of an economic downturn (p.218)." While practitioners view the potential shocks to the supply of capital as having the first order impact in shaping financial decisions, academic corporate finance has focused more on the demand for capital as the key determinant in security design (see for example Baker (2009)).

Do macroeconomic conditions in fact influence firms' capital raising? If so, what is the channel through which they operate? How do they affect firms' choices of securities, the structure of those securities, and firms' very access to the capital markets? In this paper, we address these questions using a sample containing detailed information on 21,657 publicly-traded debt issuances, 7,746 seasoned equity offerings, 40,097 syndicated loans, and 12,048 private placements in the U.S. between 1971 and $2007 .{ }^{1}$

Existing theories have a number of predictions about the relation between macroeconomic conditions and the structure and availability of security issues. These theories can be broadly classified into two groups, one based on firms' changing demand for certain types and quantities of financing over the business cycle, and the other based on supply-of-capital effects, driven either by a contraction in available funds or through changes in investor demand for relatively safe securities. The demand-forcapital mechanism typically is based on changes in information asymmetries or adverse selection costs

\footnotetext{
${ }^{1}$ Syndicated loans tranches are available for the latter part of our sample (from 1988 to 2007), and private placement are available from 1981 to 2007. The primary sources of capital omitted from this sample are regular bank loans and commercial paper.
} 
over the business cycle. ${ }^{2}$ If the adverse selection costs associated with asymmetric information between firms and investors is negatively related to overall business conditions, poor macroeconomic conditions will lead firms to issue less information-sensitive securities, shifting from equity to convertibles, and from convertibles to debt. Traditional demand-based theories have found success in explaining cross-sectional differences in corporate financing decisions, but have been less successful describing the time-series of issuance decisions (Baker (2009)).

The second mechanism by which macroeconomic conditions can affect the distribution of financing choices is through their effect on the supply of capital. Holmstrom and Tirole (1997) explain how economic downturns can create a "credit crunch" that reduces the availability of intermediary capital, especially for lower-rated firms. In addition, downturns can affect not only the availability of capital but also the types of securities that investors demand. If volatility and economic uncertainty increase during recessions, "flight to quality” models such as Caballero and Krishnamurthy (2008) and Vayanos (2004) suggest that investors will become more risk averse, leading them to sell risky assets and to purchase relatively safe assets instead. Flight to quality models predict that poor macroeconomic conditions lead the supply of capital (i.e. demand for securities) to shift toward higher credit quality and lower volatility because of a change in the relative prices of risky and safe assets.

These explanations are not mutually exclusive, so it is possible that macroeconomic conditions could affect both the demand and supply of capital, or neither of them. Both demand and supply of capital-based arguments conceivably could affect the quantity of capital raised by firms, the type of securities they use to raise this capital, and the way in which these securities are structured.

Our econometric analysis suggests that macroeconomic conditions affect both firms' abilities to raise capital and the manner in which they raise it. We also find that cyclicality of different types of securities depends on the credit quality of the issuing firms. For example, consistent with the prior literature, the aggregate issuance of public equity over time is pro-cyclical. But this relation is driven

\footnotetext{
${ }^{2}$ Examples of demand-based models of security choice are Choe, Masulis and Nanda (1993) and Bolton and Freixas (2000).
} 
primarily by noninvestment-grade borrowers, for whom public equity issuances, as well as (noninvestment-grade) bond issuances are pro-cyclical. In contrast, for investment-grade borrowers, public issuances of equity do not decline during downturns and issuances of both convertible and straight public bonds are countercyclical. Similarly, during downturns, private loans significantly increase for investment-grade borrowers but they significantly decline for noninvestment-grade borrowers.

These differences between investment-grade and noninvestment-grade firms in their capital raising patterns over the business cycle are difficult to reconcile with demand-based theories of capital raising. They are more consistent with the supply of capital shifting toward less risky securities during worse economic times. Noninvestment grade firms raise capital when they can during strong economic conditions and appear to be shut out of the public capital markets during poor economic conditions. Higher quality firms take advantage of the increased demand for their higher rated securities and actually increase their capital raising during macroeconomic downturns.

A prediction of the flight-to-quality hypothesis that does not also come from the information arguments concerns the uses of the funds that are raised. The flight-to-quality theories predict that the increased demand for safer securities in recessions will make issuing them relatively attractive, so that high quality firms will issue debt and keep the proceeds as cash in recessions, while lower quality firms will spend all capital they raise and not keep any as incremental cash. Consistent with the flight to quality hypothesis, we find that investment grade firms tend to hold a larger proportion of capital raised in the form of cash during recessions than in normal times, suggesting that the change in the relative prices of high quality bonds induces a firm to issue, rather than raising the financing to invest in real assets.

In addition to the choice of securities, we also find that market-wide factors affect the structure of debt contracts. In particular, market downturns decrease the expected maturity of public bonds and private loans, and increase the likelihood that these loans are secured. These findings are consistent with both views: poor macroeconomic conditions could lead firms to structure securities in ways that lessen their information sensitivity or an increase in investor demand for relatively safe securities could lead firms to issue securities with shorter maturities and more security. 
Taken together, the empirical results tend to support the view that the supply of capital has a larger impact than the demand for capital on corporate finance during economic downturns. First, public bond issues, particularly those with high credit quality and short-term maturity, are countercyclical. Second, the pro-cyclicality of bank loans and public bonds for lower-quality firms is contrary to the demand-based information asymmetry hypothesis, in which firms prefer financing sources with a lower sensitivity to information in response to a market downturn. Third, we find that the relative prices of highly rated bonds to bonds of lower credit quality shifts during recessions. Specifically, the AAA to BAA credit spread increases during recessions, consistent with an increase in investor demand for safer securities (or the supply-of-capital arguments). Finally, investment grade firms hold a larger proportion of the funds from the bond issue in the form of cash during recessions compared to expansions, consistent with the hypothesis that firms respond to changes in the relative prices of securities.

This paper extends the literature on security choice in a number of ways. Important early contributions to this literature are Jung, Kim and Stulz (1996) Lewis, Rogalski, and Seward (1999), and Gomes and Phillips (2007) whose concern is how firm-level factors influence the choice of securities. Gomes and Phillips (2007) in particular analyze a variety of securities including both public and private issues of debt and equity and find support for the view that information asymmetries are an important factor in firms' choice of which security to issue. We extend these papers by considering how macroeconomic effects change these choices at the margin, because macroeconomic factors affect the nature of information asymmetries and also the supply of capital. As such, our paper is in the tradition of Choe, Masulis and Nanda (1993) and Korajczyk and Levy (2003), focusing on the details of how firms raise capital and how the capital-raising process changes over the business cycle. To our knowledge, our paper is the first to evaluate the different implications of demand versus supply based theories about security issues over the business cycle, considering a menu of securities broader than between equity and public debt, including convertibles, private debt, and private placements, as well as alternative characteristics of public and private debt such as maturity and security. 


\section{Data Sources and Sample Description}

\section{A. Data Sources}

We obtain data on security issues from three different sources: SDC Global New Issues Database for public SEOs and private placements of both equity and debt, Mergent Fixed Income Securities Database (FISD) for convertible bonds and other public debt, and Loan Pricing Corporation's Dealscan for private loans. The SDC database provides information on total proceeds and the number of primary and secondary shares offered for each SEO. We drop SEOs that only offer secondary shares since these offerings do not lead to a capital inflow to the firm. This process leads to a sample of 7,746 SEOs occurring between 1971 and 2007. From SDC, we also obtain information on 12,048 private placements of equity and debt between 1981 and 2007.

Mergent FISD provides comprehensive information for U.S. corporate debt, including total proceeds raised as well as other characteristics such as maturity, security, convertibility, and credit quality. We utilize all public debt issues made by industrial firms reported in FISD from 1971 to 2007. Our initial public bond sample consists of 21,657 issues from 3,072 firms with Compustat identifiers. The average initial maturity is 12 years and the median is 10 years. Most of the bonds are unsecured (96.3\%) and slightly more than half (55\%) have investment-grade ratings.

Our data on bank debt are from Loan Pricing Corporation's Dealscan, which contains detailed issuance-level information on the characteristics of syndicated and sole-lender bank loans. These characteristics include size and maturity of the loan, credit quality of the borrower, as well as information on whether the loan is secured by some type of collateral or not. Each loan can have multiple tranches, each of which contains different characteristics. Our sample comprises 40,097 completed loan tranches to 7,465 firms with Compustat identifiers between 1988 and 2007, including 364-day facilities (9.58\%), bridge loans (1.6\%), term loans (29.84\%), and revolving loans and credit lines (58.98\%). ${ }^{3}$ The mean loan

\footnotetext{
${ }^{3}$ We thank Amir Sufi and Michael Roberts for sharing Compustat identifiers that allow us to match Dealscan Loan data with accounting data from Compustat. See Chava and Roberts (2008) for a discussion of the process of gathering these identifiers.
} 
maturity is about 3.7 years with a slightly shorter median of 3.4 years. Contrary to the sample of public bonds, most of the loans are secured, with $79 \%$ of sample loans being secured by some type of collateral.

Using these issue-level data, we collapse each firm's issues at the month level. We focus on monthly issue-level data because our macroeconomic data is available monthly and we explore the manner in which macroeconomic conditions affect firms' capital raising decisions. ${ }^{4}$ We then match the firm-month observations with accounting information from most recent fiscal year end reported in Compustat and eliminate all financial firms (one-digit SIC equal to 6) and utilities (two-digit SIC equal to 49). After this process, we end up with a sample containing 7,170 firm-months with SEO issues, 2,546 firm-months with convertible bond issues, and 10,400 firm months with straight public bond issues from 1971 to 2007, 2,957 firm-months with private placements of equity and 4,547 firm-months with private placements of debt from 1981 to 2007, and also 20,322 firm-months with private loan contracts from 1988 to 2007.

For macroeconomic data, we obtain recession/expansion dates from the National Bureau of Economic Research (NBER) and GDP growth rates from the US Bureau of Economic Analysis (BEA). In addition to macroeconomic data, we consider a direct survey-based measure of the state of financial conditions provided by the Federal Reserve, called the 'Senior Loan Officer Opinion Survey on Bank Lending Practices.' This survey is a quarterly survey of approximately sixty large domestic banks and twenty-four U.S. branches of foreign banks, asking the managers of these banks how their bank is changing their credit standards. The particular variable we focus on is the net percentage of domestic respondents who claim that they are tightening standards for commercial and industrial loans. ${ }^{5}$ One limitation of this survey is that it is available only after the second quarter of 1990 , so when we use the survey data, we restrict our sample to this sub-period.

\footnotetext{
${ }^{4}$ We have estimated all equations in the paper using firm-quarter issuance data matched with quarterly Compustat data as well. Quarterly issuance data does not match perfectly with the macroeconomic data, but has the advantage of corresponding exactly with quarterly accounting data. The results using quarterly data are in all cases similar to those reported below and are available from the authors on request.

${ }^{5}$ See Lown, Morgan, and Rohatgi (2000) for more information about the survey. These authors document that the survey results are strongly related to loan growth, with tightening standards being associated with slower loan growth.
} 


\section{B. The Pattern of Security Issues over Different Macroeconomic Conditions}

Table I presents descriptive statistics of our security issuance sample. To provide a rough idea of the time-series variation in the use of securities, we divide the sample into sub-periods based on the NBER's expansion/recession classification. For each sub-period, we report the proceeds raised in constant 2000 \$US million for six types of securities in that period: SEOs, convertibles, straight public bonds, private loans, and private placements of equity and debt. Since recessions are substantially shorter than expansions during our sample period, we report the monthly average proceeds rather than total proceeds during each sub-period.

A complicating factor in our analysis is that the quantity of capital raised increased substantially over the sample period as the economy expanded even after controlling for the inflation, due in part to the development of the syndicated loan market. Given the rapid growth in the quantity of issuances, it is difficult to infer patterns about the incremental effect of macroeconomic conditions. Nonetheless, a few patterns relating macroeconomic conditions and security offerings are evident from Table I. In particular, during recessions, public equity offerings decline but public debt offerings increase. The rise of the syndicated loan market is also apparent, coming into existence in the late 1980s and becoming the predominant form of capital raising by the 2000s.

We observe a similar pattern in Figure 1, which reports the time-series trend of the natural logarithm of the proceeds raised (in constant 2000 \$US million) for each calendar month during our sample period. Shaded areas in the figure denote recessions as defined by the NBER. Figure 1 highlights the manner in which SEOs decrease during recessions while public bonds and convertibles increase.

Table II normalizes the value raised through each method of raising capital in each calendar month by the total capital raised in that particular month, and documents the way in which the fraction of capital raised by different methods varies over macroeconomic conditions. We measure macroeconomic conditions using three alternative measures. In addition to an NBER-defined recession, we characterize months by GDP growth, and label a month 'Low Growth' if GDP growth in that particular quarter is below the $25^{\text {th }}$ percentile of economic growth over the entire sample period. Finally we define 'Weak 
Credit Supply' months as those for which the net percentage of senior loan officers indicating that they are tightening standards for loans to large and medium firms is positive for that particular quarter.

Panel A of Table II presents the proceeds raised through alternative forms of financing for the 1971-1987 sub-period, for which there are no syndicated loans, while Panel B reports the results subsequent to 1988, the first year for which we have data on syndicated loans. For both sub-periods, the fraction of capital raised by public debt is larger during market downturns than in expansions. In contrast, public equity issues are pro-cyclical, with larger fractions being raised during expansions than contractions. Macroeconomic conditions have a somewhat ambiguous effect on convertibles; in the earlier sub-period convertibles account for a larger fraction of capital raised during expansions while in the latter sub-period they account for a larger fraction during recessions. Similar to public bonds, the fraction of private placements of both equity and debt generally increases in worse macroeconomic conditions. These results are generally consistent with the demand for capital argument that firms use more information-sensitive securities during better economic conditions.

On the other hand, the demand-driven information-asymmetry hypothesis does not do well at explaining patterns in private bank loans. Private debt appears to account for a higher fraction of capital raised during expansions than recessions, in contrast to the information hypothesis, which suggests that bank loans should be countercyclical. The observed pattern is better explained by the supply of capital changing over the business cycle, so that in recessions overall intermediary capital declines sufficiently to more than offset the substitution from public to private debt for monitoring reasons.

In addition to the broad type of securities offered, the quality and structure of the securities used to raise capital also potentially vary depending on macroeconomic conditions. Table III breaks down the public debt issues more finely, documenting the extent to which the use of bonds of different maturity, security, and quality vary by market conditions. In the first two columns we report the relative proportion of short-term public debt, as well as secured public debt. ${ }^{6}$ We define a bond to be short-term if the time

\footnotetext{
${ }^{6}$ Mergent does not contain any short-term debt issues prior to 1985 . Hence, we consider short-term debt to be missing before 1985 when computing the numbers presented in Table III.
} 
to maturity of the issue is less than five years. ${ }^{7}$ Our measure of security level is a dummy variable set to one if the bond is secured and set to zero otherwise. If the firm issues more than one bond in a particular month, we consider the observation to be secured if the proceeds raised from the secured bond is at least half of the total proceeds raised.

The first column of Table III indicates that the relative proceeds raised through short-term debt increase significantly during recessions and weak credit supply. However, the results for secured debt in the second column of Table III are more ambiguous, with the proportion of debt that is secured being somewhat higher in good economic times than in downturns. The remaining columns of Table III present the fraction of capital raised by public debt with different credit quality across varying macroeconomic conditions. The pattern here is clear: Lower quality and unrated debt issues decline substantially during poor market conditions. During recessions, the quantity of low-quality issues declines to one third to one half of the expansion levels, depending on the sample period used. In contrast, the level of investable Brated issues is about the same, leading the fraction of A-rated issues to increase by about twenty percentage points during recessions. The pattern is similar if we measure market conditions using GDP growth or the survey of credit supply, although the differences are somewhat smaller.

Figure 2 illustrates this pattern graphically. The vertical axis measures the natural logarithm of proceeds raised (in constant 2000 \$US million) through public bonds of various quality. The figure suggests an overall upward trend in the use of public debt financing in all levels of credit quality. However, it also points out the differential impact of a recession on the public debt with different ratings. During recessions, the quantity of capital raised by low-rated and non-rated debt issues drops significantly while highly-rated bonds remain relatively constant or even rise.

\section{Firm Characteristics}

In addition to market-level characteristics, firm-level characteristics affect both the likelihood of raising capital, and conditional on raising capital, the method used to raise the capital. To illustrate how

\footnotetext{
${ }^{7}$ If the firm issued more than one bond in a given month, then the issue activity is classified as short-term if the proceeds-weighted maturity of the bonds is less than five years.
} 
firm-level differences vary with the frequency capital raising, the first two columns of Table IV compare characteristics of firms in months in which some type of security was offered to months in which no security was issued. These characteristics are firm size (natural logarithm of total assets), market leverage, market to book, cash flow, cash, the inverse of interest coverage, a debt-rating dummy, sales growth, and the past stock return. Inverse interest coverage is defined as the natural logarithm of $\left(1+\right.$ interest/EBIT) and stock return is calculated over the previous twelve months. ${ }^{8}$ The accounting variables reported are taken from the fiscal year-end immediately prior to the issue.

Relative to firm-months with no issues, firms in issuing months tend to be larger, older, and have higher growth and better prior stock performance. For the issuing months, the average sales growth for the year just prior to the security issuance is 0.27 during the whole sample period, compared to 0.18 for non-issuing months. The stock return over the previous twelve months is 0.36 for issuing months compared to 0.17 for non-issuing months. In addition, issues are less likely during market downturns in most cases, regardless of which measure of financial conditions one uses.

The remaining columns of Table IV summarize differences in firm characteristics across issuers of alternative securities. Equity issuers tend to be the smallest, youngest, and have the highest market to book ratios. Public debt issuers are substantially larger, and have higher fixed asset ratios than issuers of other types of securities. In contrast, issuers of private loans and private placements of debt are noticeably smaller than public debt issuers, with lower cash flows and fixed assets. This pattern suggests that public debt issuers are noticeably different from other kinds of issuers, consistent with the view that publiclytraded debt is the most attractive form of financing, and that firms using other forms are unable to issue publicly-traded debt.

\section{Multivariate Analysis of Security Choice}

The aggregate statistics and the univariate comparisons are both suggestive of the hypothesis that firm characteristics and macroeconomic conditions affect the way firms raise capital. However, to

\footnotetext{
${ }^{8}$ Appendix Table 1 contains detailed definitions of all variables.
} 
identify the effect of macroeconomic conditions on the issuance of the firms' funding choices, it is important to estimate this relation in a multivariate setting, controlling for firm-level factors and time trends. Consequently, we employ discrete-choice models that estimate the likelihood of a firm issuing a specified type of security in a particular time period. At any point in time, a firm can choose not to obtain financing, to obtain a private loan, to issue private placements of either equity or debt, or to access the public security markets by issuing a straight bond, convertible bond, or seasoned equity. Given the number of potential alternative outcomes, we utilize econometric approaches that allow for multiple discrete choices.

\section{A. A Multinomial Logit Approach}

Multinomial logit models provide one way to estimate systems in which independent variables affect the choice among a finite number of alternative outcomes. Thus, it provides a natural way of modeling a firm's choice of how to raise capital given alternative financing methods, or not to raise capital at all. ${ }^{9}$ Specifically, we estimate the following model:

$$
\operatorname{Pr}(\text { security type }=j)=\frac{e^{\beta_{j}^{\prime} X}}{\sum_{k=0}^{6} e^{\beta_{k}{ }^{\prime} X}}
$$

where $j$ equals 0 if the firm does not issue any type of security, 1 for a bank loan, 2 for a public bond, 3 for a convertible debt, 4 for an SEO, 5 for a private placement of equity, and 6 for a private placement of debt. $\beta_{j}$ is a vector of coefficients for outcome $j$ where $\beta_{0}$ is assumed to be zero, and $X$ is a vector of explanatory variables.

Panel A of Table V reports estimates of this equation. In each specification, 'no issue' is the omitted variable, so the coefficients in each column can be interpreted as the impact on the probability of issuing a particular type of security relative to not issuing at all. Specification (1) uses the NBER-defined

\footnotetext{
${ }^{9}$ One potential drawback to multinomial logit is the underlying independence of irrelevant alternatives assumption, which requires that the choice between any two financing choices be independent of the existence of a third choice. For example, the multinomial logit specification implicitly assumes that the choice between public debt and private debt is independent of the choice of whether or not to issue seasoned equity. See Greene (2000) pp. 857-862, and 875-879 for more discussion on the estimation and properties of multinomial logit.
} 
recession as our measure of market conditions, while (2) uses the level of GDP growth. We also report results of a model using the Senior Loan Officer Opinion survey on lending standards in Appendix Table 2. Each specification also includes a number of variables designed to capture the firm's financial condition and demand for capital (e.g., market to book, cash flow, and sales growth). Other firm-level controls are firm's age, natural logarithm of the total assets, market leverage, cash, natural logarithm of the inverse of interest coverage, ${ }^{10}$ and a debt-rating dummy. We also include the firm's stock return for the prior twelve months, which restricts our sample to listed firms. Furthermore, we include the term spread, defined as the difference between the yields on ten-year treasuries and one-year treasuries, as a macro-level control. Finally, all equations include industry fixed effects. ${ }^{11}$ The equations are estimated using a panel of monthly observations for all firms that had at least one type of security issue at any point during the sample period, a procedure that leads to 728,639 observations. ${ }^{12}$ We calculate the standard errors in these equations allowing for clustering of observations at the firm level.

In Panel A of Table V (and also in Panel A of Appendix Table 2), the coefficient on the variable indicating poor macroeconomic conditions is negative and statistically significantly different from zero for SEOs, using all measures of the downturns. Additionally, the SEO coefficient is statistically significantly different from the coefficients on the other securities in the specifications using the recession dummy and the weak credit market dummy variable as our measures of financial conditions. This result indicates that a recession lowers the likelihood of issuing an SEO, relative to not issuing any security or issuing any other type of security and is consistent with the notion that as financial conditions worsen, firms are less likely to issue public equity. As such, it confirms the findings of Hickman (1953), Moore

\footnotetext{
${ }^{10}$ The transformation used is a negative function of conventional interest coverage, so that the negative coefficient on this variable for a specific security type means that better interest coverage increases the likelihood of the corresponding issue type. We use this transformation because the usual measure of interest coverage becomes infinite for all-equity firms.

${ }^{11}$ One exception is in Panel C below, for which the multinomial logit model does not converge when we include industry fixed effects. We also ran the regressions reported in Panel B for noninvestment-grade borrowers without industry fixed effects and found similar results.

${ }^{12}$ We obtain similar results when we include all other firms in Compustat that did not have any security issue during the sample period.
} 
(1980) and Choe, Masulis and Nanda (1993), who find similar patterns of security issuances over earlier time periods (1900-1938, 1946-1970, and 1971-1991 respectively).

Convertible bonds appear to be more likely to occur during poor economic times, holding other factors constant. All three coefficients on the variables indicating poor financial conditions are positive (see Panels A of Table V and Appendix Table 2), and two of them are statistically significantly different from zero. These results provide evidence for the argument that firms that otherwise would be issuing public equity choose to issue a convertible bond during market downturns. Given that asymmetric information likely increases during these downturns, this pattern is consistent with the logic of the Stein (1992) model, in which convertible bonds are issued as an alternative to equity when asymmetric information is high.

The other coefficients in the equations in Panel A of Table V are consistent with the view, implicit in the Holmstrom and Tirole (1997) model among others, that the firms issuing public debt are the lowest quality risks to a lender. These coefficients indicate that, relative to firms that issue other types of securities (or no issue at all), public debt issuers are oldest and are most likely to have a debt rating. In addition debt issuers in general are larger than firms that issue equity either publicly or privately.

Because the supply of capital arguments imply that recessions should affect poorly-rated firms’ access to capital more than highly rated ones, we reestimate these equations on subsamples of noninvestment-grade and investment-grade borrowers in Panels B and C of Table V, as well as Appendix Table 2, Panels B and C. We define investment-grade firms as those that ever issued at least one investment-grade public bonds during the whole sample period.

The results from these panels imply that a firm's quality leads to very different capital-raising patterns over the business cycle. The coefficient on the issuance of public equity remains negative and significant for noninvestment-grade borrowers in all specifications. However, for investment grade borrowers, it is consistently positive although not statistically significant. In addition, issuances of convertible bonds do not appear to be countercyclical for non-investment grade firms while they are strongly countercyclical for investment grade firms. 
In the estimates using the entire sample in Panel A of Table V, we do not observe an increase in the quantity of public bonds and bank loans during economic downturns, which is difficult to reconcile with issuers shifting towards less information sensitive financing sources as predicted by the demandbased theory. However, when we break down our estimates into noninvestment-grade and investmentgrade firms in Panels B and C of Table V and Appendix Table 2, it becomes clear that combining firms of all quality masks important differences in the borrowing behavior between noninvestment-grade and investment-grade firms over the business cycle. In particular, these estimates imply that private loans significantly increase for investment-grade borrowers but they significantly decline for noninvestmentgrade borrowers, consistent with the view that capital available to intermediaries goes down and consequently they tighten lending standards during down cycles. We see a similar pattern for public bonds: the coefficient on issues of public bonds is negative and statistically significant for noninvestmentgrade borrowers while it is positive and statistically significant for investment-grade borrowers.

Both the credit crunch and flight to quality (supply-based arguments) predict that we should observe better quality firms issuing debt during recessions than during expansions. The credit crunch arguments suggest that capital is rationed from the poorly-rated firms and that only the highly-rated ones can receive financing. In addition, the flight to quality arguments compound this effect because they imply that financiers will prefer lending to highly-rated firms during recessions. This argument is commonly made by practitioners, who often claim that one reason for having a high bond rating is to avoid getting shut out of the debt market during poor economic times (see Passov (2003) and Graham and Harvey (2001)). Thus, a clear prediction of the supply of capital arguments is that a higher fraction of issuances of debt should be of high quality during recessions than during expansions.

Our findings provide strong support for these commonly discussed arguments of practitioners, as well as the credit crunch and flight-to-quality arguments. During bad economic times, poor quality borrowers appear to be shut out of the bond market. The only bonds that are not affected by poor economic times are highly-rated ones. In other words, the fact that the quality of bonds issued is strongly countercyclical is evidence consistent with the view that financial constraints are exacerbated during 
recessions. This finding mirrors the patterns reported in Kahle and Stulz (2010), who report that large investment-grade firms’ capital raising was not substantially affected by the Financial Crisis of 2008.

Could changing demand for capital be responsible for these effects? In other words, could it be possible that poorly rated firms simply demand less capital during recessions than during expansions? This pattern of demand seems unlikely, since poorly rated firms typically are relatively highly cyclical and will require more outside funding during poor economic times. The fact that poorly rated firms often require a Chapter 11 reorganization to obtain DIP financing during recessions is strongly suggestive of the notion that they have trouble raising outside capital at these times. Consistent with the prior literature (for example, Hertzel and Smith (1993)) arguing that firms under information asymmetry choose private placements, lower-quality firms in our sample seem to be relying more on private placements, especially of equity, during downturns (see Panels B of Table V and Appendix Table 2 for the positive and significant coefficient for noninvestment-grade borrowers).

Consistent with this logic is the strong negative relation between cash holdings and the probability of issuing investment grade debt. As argued by Almeida, Campello and Weisbach (2004, 2009), more financially constrained firms are likely to save a higher percentage of cash from their cash flows. Firms with low bond ratings are more likely to face financial constraints, so they will tend to save more cash, leading to a negative relation between firms' cash holdings and the ratings of the bonds they issue. During recessions, poorly rated firms use up their cash reserves since they cannot raise capital. Consequently, the relation between business conditions and the quality of issuances is likely driven by supply of capital rather than demand for capital considerations. ${ }^{13}$ In the next section, we analyze the uses of funds for borrowers with different credit ratings in detail.

\section{B. Uses of Funds from Capital Raising Activities over the Business Cycle}

\footnotetext{
${ }^{13}$ One objection to this "constraints" view is that there must be some interest rate at which poorly rated firms can issue public debt during recessions. But that rate must be sufficiently high so that the firms choose to draw down their cash and lines of credit rather than paying it. If this were the case, it is nonetheless the limited supply of capital that ends up leading to poorly-rated firms not issuing public debt during recessions.
} 
The flight-to-quality hypothesis shares many of the same predictions as the demand for capitaldriven information hypothesis. In particular, both suggest that the distribution of external financing choices shift towards securities of less information sensitivity or lower risk during a downturn. The flight-to-quality hypothesis, however, contains the additional prediction that investors' demand for safer securities changes the relative prices between securities of different risk. If, as predicted by the flight-toquality models, investor demand shifts toward safer securities in response to a poor macroeconomic environment, there should be a shift in the relative prices of securities of different quality. Confirming this hypothesis, Figure 3 reports the time-series trend in AAA and BAA corporate bonds as well as the difference between the two. The figure clearly indicates that credit spread increases in recessions making higher quality debt more attractive to issue. As Baker (2009) argues, firms have an incentive to issue these safer securities when their relative prices have dropped. Consequently, we expect the distribution of securities issuance choices to shift towards relatively safer assets, such as from equities to bonds, similar to the prediction of the asymmetric information hypothesis.

One key difference between these hypotheses is that in the demand for capital-driven information story, firms issue securities when they have a need for external financing, such as for investing in fixed capital. In contrast, if firms are issuing securities in response to changes in relative prices due to a flight to quality episode, firms are more likely to hold the funds as cash, rather than to invest the proceeds immediately. Thus, one way to distinguish whether macroeconomic conditions are changing issuance choices directly through information asymmetries or indirectly through affecting investor demand for securities is to investigate differences in the uses of proceeds from the capital raising activities across the business cycle.

To examine the effect of macroeconomic conditions on the ex-post uses of funds from new capital raised, we first aggregate all proceeds raised from different security types within a calendar quarter. We then match the most recent fiscal quarter before the issuing quarter and the most adjacent 
fiscal quarter after the issuing quarter. ${ }^{14}$ We then estimate equations similar to those reported in Kim and Weisbach (2008), using the following specification:

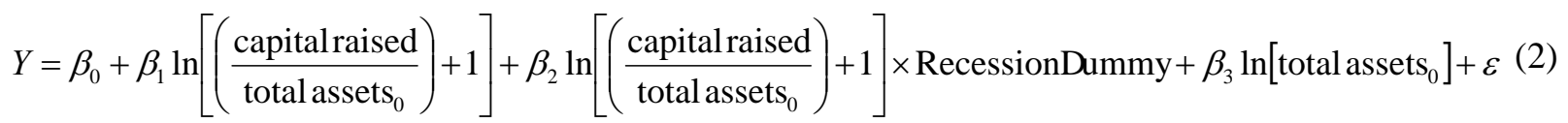

where $Y=\ln \left[\left(\left(V_{t}-V_{0}\right) /\right.\right.$ total assets $\left.\left._{0}\right)+1\right], V$ is quarterly cash and short term investments, and $t$ is the number of fiscal quarters subsequent to the issuing quarter. We estimate the uses of capital from proceeds raised depending on both firm quality and macroeconomic conditions. We classify a firm as noninvestment-grade if it never issued an investment-grade public bond during the whole sample period based on Moody's ratings. We define a calendar quarter as being in a recession if that quarter includes a recession month based on NBER classification. We estimate equation (2) for intervals of one quarter, four quarters and eight quarters following the issuing quarter.

We present estimates of equation (2) for noninvestment grade and investment grade issuers separately in Table VI. The first four columns report the coefficient estimates and $t$-statistics for noninvestment grade firms and the remaining columns present the corresponding numbers for investment grade firms. The results reported in the first three row aggregates all sources of external capital raised in a given calendar quarter. The remaining lines report the results separately for each different sources of financing.

The coefficient $\beta_{1}$ measures the proportion of proceeds raised in an issue used to increase cash (including short-term investments) during expansions while $\beta_{2}$ captures the incremental impact of a recession on the fraction held in cash. ${ }^{15}$ A direct implication of the flight-to-quality arguments comes from the effect of proceeds raised on increases in cash and short-term investments. In expansions, lower quality firms save a substantially higher portion of the capital raised than high quality firms, consistent with the usual precautionary savings motive (see Almeida et al. 2004). That is, $\beta_{1}$ for noninvestment-

\footnotetext{
${ }^{14}$ For March, June, September, December firms, the most adjacent fiscal quarter would be the same as the issuing calendar quarter.

${ }^{15}$ Cash excluding short-term investments is often missing in quarterly Compustat, which is the main reason why we resort to cash including short-term investments.
} 
grade firms are higher than those for investment-grade firms in most cases. However, in recessions, low quality firms save much less of the capital they raise for all sources of financing taken together, as well as for vast majority of different financing sources, regardless of the intervals. In contrast, during down cyles, investment-grade firms save substantially more from all financing sources as a whole and especially from SEOs and public bonds than they do in expansions. This pattern is consistent with the flight-to-quality arguments: In recessions the cost of raising capital for low-quality firms is relatively high, so they raise capital only when it is absolutely necessary to fund investments. In contrast, the price of capital is abnormally low for high quality issuers during recessions, so they will actually increase their issuances beyond what is necessary to fund investments and save the proceeds as cash.

\section{Market Conditions and the Design of Debt Contracts}

An additional testable implication provided by both demand-based and supply-based hypotheses is that, conditional on the type of security used, firms will alter the structure of those securities depending on macroeconomic conditions. Regardless of the type of security used, we expect to observe that as market-wide conditions weaken, firms will adjust the design of their securities either to minimize their sensitivity to information or in response to relative price changes as investors' demand for safer assets increases. ${ }^{16}$

\section{A. Publicly-traded Bonds}

We first examine how the characteristics of public bonds vary over the business cycle. Both the information-sensitivity and risk profile of a bond increases in the bond's maturity and decreases when a bond is secured with real assets, holding all other factors constant. Therefore, we expect to observe that, all other things equal, firms are more likely to use shorter maturity bonds or secured bonds when market conditions are relatively poor.

\footnotetext{
${ }^{16} \mathrm{~A}$ related implication of this argument is that lenders should impose tighter covenants on borrowers during recessions. Zhang (2008) examines this hypothesis on a sample of large US firms and finds that covenants are stricter when set during downturns and they lead to higher recovery rates later. Similarly, Santos and Winton (2008) find that loan spreads rise in recession more so for those without public debt market access.
} 
We estimate equations predicting whether the bond is short term and whether the bond is secured, conditional on an issuance of public debt. We restrict the sample to those firm-months for which there is a bond issue, so there are two possible outcomes, either short-term or long-term, and either secured or non-secured and estimate the following logit models. ${ }^{17} 18$

$$
\begin{aligned}
& \operatorname{Pr}(\text { bond maturity }=\text { short term })=\frac{e^{\beta^{\prime} X}}{1+e^{\beta^{\prime} X}} \\
& \operatorname{Pr}(\text { bond security }=\text { secured })=\frac{e^{\beta^{\prime} X}}{1+e^{\beta^{\prime} X}}
\end{aligned}
$$

where $\beta$ is a vector of coefficients for short-term debt in equation (4) and secured debt in equation (5), and $X$ is a vector of firm characteristics and financial conditions.

Panel A of Table VII contains estimates of these equations. The first three columns of this table report the estimates for equation (3). The results suggest that financial conditions and the maturity of publicly-traded bonds are negatively related. The coefficients on the variables representing poor conditions are all positive and statistically significant. This finding is consistent with the notion that weak macroeconomic conditions exacerbate asymmetric information problems, since shorter maturity securities' value fluctuates less with changes in information about firm value than does longer maturity securities' value. However, to the extent that short-term bonds are less risky-than long-term bonds the results can also be explained by a flight to quality within this asset class.

Additionally, consistent with the Diamond (1991) liquidity-risk arguments, we find that shortterm debt issuers tend to be larger, have stronger growth opportunities, and less cash on the balance sheet than firms that can issue long-term debt. The large effect of growth opportunities, as measured by the

\footnotetext{
${ }^{17}$ There are some months for which a firm issues more than one bond. In these cases, we define short-term firmmonths as those with proceeds-weighted initial maturity of less than or equal to five years. Similarly, secured firmmonths are defined as those with proceeds-weighted secured dummy greater than or equal to 0.5.

${ }^{18}$ We have estimated a number of alternative specifications that we have reported in previous drafts. In particular, we have estimated two-stage models in which we first estimate the likelihood of a bond issue, and then estimate, conditional on the issue, the factors that affect the structure of the issue. We have also estimated multinomial logit models in which firms face a choice of not to issue, to issue short-term, or to issue long-term (and similarly with security). As the results from each specification are similar, we choose to report results from the simpler specification.
} 
market-to-book ratio, is also consistent with Myers (1977) and Barnea, Haugen and Senbet (1980), in which firms with better growth opportunities issue on shorter term maturities to help minimize potential agency conflicts. The results are also largely consistent with the Flannery (1986) signalling model in that short-term debt issuers seem to be of higher quality being older, larger and having more growth options compared to long-term debt issuers.

Columns (4), (5), and (6) report estimates of equation (4), which contains the factors that affect the likelihood that a particular bond is secured. These estimates for bond security are more difficult to interpret than those for maturity. For the low-growth dummy, the coefficient is positive and significantly different from zero. However, the coefficients on the other financial condition variables are insignificantly different from zero with opposite signs from one another.

In addition, the results from Panel A of Table VII document the firm-level factors that affect the decision to use secured debt. These results suggest that firms issuing secured debt tend to be smaller and much more highly levered than unsecured issuers. Firms also tend to issue secured debt when they have high fixed asset ratios and after periods of poor stock returns. They tend to hold more cash, which indicates that firms issuing secured debt are concerned about liquidity constraints in the future. These findings are consistent with the 'banking' view of secured debt (Berger and Udell (1990)), which focuses more on the effect of (limited) supply of capital and catering to investors' demands on financial choices. Here, poor quality firms have little choice but to issue secured debt as investors are more likely to require direct collateral when the firm is nearing bankruptcy. On the other hand, they do not support the traditional demand-driven 'corporate finance' view, in which high quality firms issue secured debt to avoid underinvestment problems associated with the priority of existing debt claims (Stulz and Johnson (1985), Smith and Warner (1979), and Berkovitch and Kim (1990)).

\section{B. Private Loans}

We next examine the way in which macroeconomic conditions and firm-specific factors affect the structure of private loans. As with our analysis of public debt offerings, we classify private loans by maturity and security level. As before, we consider a loan or collection of loans to be short-term if the 
weighted maturity is less than five years, and classify the loans as secured if the proceeds-weighted secured dummy is larger than or equal to 0.5 . We then estimate equations predicting the factors that affect whether a loan is short or long-term, and whether or not it is secured. Similar to the equations (3) and (4) estimated for bonds, we restrict our sample to those firm-months for which a loan was issued, and estimate the equations using a logit model.

Panel B of Table VII presents estimates of these equations. The first three columns report estimates of the factors that affect the choice between short-term and long-term loans. Similar to public bonds, the conditional probability of obtaining a short-term loan increases during economic downturns and tightening credit markets, consistent with the hypothesis that firms turn away from more informationsensitive or risky loans during downturns. In addition, firms that get short-term private loans tend to be smaller, have lower debt levels, and are less likely to have obtained a credit rating than firms that obtain long-term loans. These findings are in contrast to those for short-term bond issuers, who tend to be larger firms that have credit ratings.

The last three columns of Panel B of Table VII report estimates of equations predicting whether a given loan will be secured or unsecured. The coefficients on the three indicators of financial market conditions are positive and statistically significant. These results suggest that weak credit conditions are associated with a higher use of secured relative to unsecured loans.

The effect of macroeconomic conditions on security appears to be different for loans, where market downturns clearly increase the likelihood of security, than for bonds, where this effect is significant only for one of three measures of financial conditions. One possible explanation is that secured public debt is relatively rare, with only 5 percent of issues being secured. In contrast, $79 \%$ of private loans in our sample are secured. Thus, it is not surprising that the results for security are more clear cut for the sample of loans, where security is a common feature, than for bonds, where it is not.

In addition, the same firm-level factors that lead firms to issue secured public debt lead firms to use secured private loans. In particular, firms obtaining secured loans tend to be younger, smaller, highly levered with low interest coverage and weak cash flows. Similar to the results from the public debt, this 
pattern strongly supports the supply of capital-driven 'banking view' of secured debt, in which firms tend to use secured debt in situations in which lenders are unwilling to lend absent security. It is counter to the demand for capital-driven 'corporate finance' view, in which firms use secured debt as a way of finessing future agency problems.

\section{Discussion}

Macroeconomic conditions are widely believed to affect the way in which firms raise capital, and indeed their very ability to do so. There are a number of theories that predict a relation between the way in which firms raise capital and macroeconomic conditions. These theories can broadly be categorized into demand for capital-based theories, which are usually based on information asymmetries, and supply of capital based theories, which argue that recessions decrease the supply of capital, especially to poorly rated firms, through a combination of a credit crunch and a flight to capital. Both demand and supplybased theories have predictions for the types of securities that are offered at different points in the business cycle, the way that securities are structured at different points in the business cycle, and the types of firms that issue securities at different points in the business cycle.

We evaluate the way in which macroeconomic conditions affect capital raising using a sample of capital-raising activities by US corporations, including 7,746 seasoned equity offerings, 21,657 public debt offerings, 12,048 private placements of equity and debt, and 40,097 private loans. Using these data, we obtain a set of stylized facts about the types of securities issued at different points in the business cycle, the way these securities are structured at different times, and the financial soundness of the firms that issue at those times.

When interpreting these findings, there are two main questions to be asked. First, do macroeconomic conditions affect capital raising at all? Second, which theories best explain which of the particular patterns of a particular type of capital raising?

The answer to the first question is clear: Macroeconomic conditions are an important determinant of capital raising. They impact the types of securities used by firms, the way these securities are 
structured, and perhaps most importantly, the types of firms that are able to receive financing at different points in time.

The effect of macroeconomic conditions on capital raising differs substantially depending on the financial soundness of the firm in question. For lower-rated, noninvestment-grade firms, the likelihood that it raises capital decreases when overall market conditions worsen, regardless of whether we measure this worsening by an NBER-defined recession, the growth rate of GDP, or credit tightness due to a Federal Reserve Survey of bankers. For these firms, the likelihood they receive a loan, issue a bond, or issue public equity all decline with poor macroeconomic conditions. The only manner of capital raising that increases for these firms in poor economic times is private placements of equity and debt. These results are consistent with the view that when macroeconomic conditions worsen, the supply of capital shifts and relatively poor quality firms cannot issue capital publicly but instead have to rely on private placements.

However, the supply of capital does not appear to decline for higher-rated firms during poor macroeconomic conditions. For higher-rated, investment-grade firms, public equity issues have no relation with the business cycle, while public bond issuances and private loans actually increase with poor financial conditions. These results are consistent with "flight to quality" arguments, in which uncertainty about the economic environment increases in downturns, leading investors to prefer lower risk investments. In addition, they are consistent with “credit crunch” stories like Holmstrom and Tirole (1997), in which capital becomes scarce during an economic slowdown and is rationed to higher quality firms.

An implication of these arguments is that during poor economic times, high quality firms' cost of capital should be relatively low, and they should raise capital to replenish their liquidity. In contrast, lower-rated firms face substantial costs to raising capital in poor economic times, so they should only raise it when necessary and spend whatever capital they raise right away. We examine these predictions, and find that, consistent with the flight to quality arguments, highly rated firms hold a relatively high 
proportion of proceeds from the issuance in the form of cash during recessions.. In contrast, low-rated firms tend to spend most of the capital they raise during poor economic times.

In addition to the choice of securities, we also consider the possibility that macroeconomic factors affect the structure of securities. In particular, we examine how macroeconomic conditions affect the maturity and security of the public and private debt issuances. Our results indicate that, holding other factors fixed, a downturn tends to decrease the expected maturity of both public bonds and private loans and to increase the likelihood that these loans are secured. These findings can be explained both by demand-based stories, in which less information-sensitive securities are issued during poor economic times, and by supply-based ones, in which suppliers of capital require a shorter maturity and more security when macroeconomic conditions are worse.

Overall, our results are consistent with the view that macroeconomic conditions are important determinants of the structure of securities issued, and, equally importantly, of the ability of firms to raise capital at all. The supply of capital available to firms as well as investors' demand for certain types of securities appear to be important determinants of the manner in which firms raise capital. These findings appear to justify the concerns of Passov (2003) that firms without investment-grade bond ratings could conceivably be shut out of the capital markets during down cycles. Indeed, in the well-known Graham and Harvey (2001) survey of Chief Financial Officers, the two most common concerns in debt policy were maintaining financial flexibility and bond ratings (p. 210). Consistent with this survey evidence are Kisgen (2008) and Hovakimian et al. (2009), who document that firms appear to target bond ratings rather than debt levels. Our findings suggest that the concern about bond ratings is potentially warranted, since firms with poor bond ratings potentially are shut out of the capital markets during downturns. 


\section{REFERENCES}

Almeida, Heitor, Murillo Campello and Michael S. Weisbach, 2004, The Cash Flow Sensitivity of Cash, Journal of Finance, 59, 1777-1804.

Almeida, Heitor, Murillo Campello and Michael S. Weisbach, 2009, Corporate Financial and Investment Policies when Future Financing is not Frictionless, Journal of Corporate Finance, forthcoming.

Baker, Malcolm, 2009, Capital Market Driven Corporate Finance, Annual Review of Financial Economics, Vol. 1, 181-205.

Barnea, Amir, Robert A. Haugen and Lemma W. Senbet, 1980, A Rationale for Debt Maturity Structure and Call Provisions in the Agency Theoretic Framework, Journal of Finance, 35, 1223-1234.

Berger, A. N., and G. F. Udell, 1990, Collateral, Loan Quality and Bank Risk, Journal of Monetary Economics 25, 21-42.

Berkovitch, Elazar and E. Han Kim, 1990, Financial Contracting and Leverage Induced Over- and UnderInvestment Incentives, Journal of Finance, 45, 765-794.

Bolton, Patrick and Freixas, Xavier, 2000, Equity, bonds and bank debt: capital structure and financial market equilibrium under asymmetric information. Journal of Political Economy 108, 324-351.

Caballero, Ricardo J. and Arvind Krishnamurthy, 2008, Collective Risk Management in a Flight to Quality Episode, Journal of Finance 63, 2195-2230.

Chava, Sudheer and Michael R. Roberts, 2008, How does financing impact investment? The role of debt covenants. Journal of Finance, 63, 2085-2121.

Choe, H., R. Masulis, and V. Nanda, 1993, Common Stock Offerings Across the Business Cycle: Theory and Evidence, Journal of Empirical Finance, 1, 3-31.

Diamond, Douglas W., 1991, Debt Maturity Structure and Liquidity Risk, Quarterly Journal of Economics, 106, 709-737.

Flannery, Mark J., 1986, Asymmetric Information and Risky Debt Maturity Choice, Journal of Finance, 41, 19-37.

Graham, John R. and Campbell R. Harvey, 2001, The theory and practice of corporate finance: evidence from the field, Journal of Financial Economics, 187-244.

Greene, W. H., 2000, Econometric Analysis, Prentice Hall.

Gomes, Armando and Gordon Phillips, 2007, Private and Public Security Issuance by Public Firms: The Role of Asymmetric Information, Working Paper, University of Maryland.

Hertzel, M., Smith, R.H., 1993. Market discounts and shareholder gains for placing equity privately. Journal of Finance 48, 459-485. 
Hickman, W. Braddock, 1953, The Volume of Corporate Bond Financing, National Bureau of Economic Research, New York.

Holmstrom, Bengt and Jean Tirole, 1997, Financial Intermediation, loanable funds, and the real sector, Quarterly Journal of Economics 112, 663-691.

Hovakimian, Armen, Ayla Kayhan, and Sheridan Titman, 2009, Crediting Rating Targets, Working Paper, University of Texas.

Jung, Kooyul, Yong-Cheol Kim, and Rene Stulz, 1996, Timing, investment opportunities, managerial discretion, and security issue decisions, Journal of Financial Economics, 159-185.

Kahle, Kathleen M., and Rene M. Stulz, 2010, Financial Policies and the Financial Crisis: How Important Was the Systemic Credit Contractions for Industrial Corporations?, Dice Center Working Paper 2010-13.

Kim, Woojin and Michael S. Weisbach, 2008, Motivations for public equity offers: An international perspective, Journal of Financial Economics, 87, 281-301.

Kisgen, Darren J., 2008, Do firms target credit ratings or leverage levels?, Journal of Financial and Quantitative Analysis.

Korajczyk, Robert A. and Amnon Levy, 2003, Capital structure choice: Macroeconomic conditions and financial constraints, Journal of Financial Economics, 68, 75-109.

Lewis, Craig, Richard Rogalski, and James Seward, 1999. Is convertible debt a substitute for straight debt or for common equity? Financial Management 28, 5-27.

Lown, Cara S., Donald P. Morgan, and Sonali Rohatgi, 2000. Listening to loan officers: the impact of commercial credit standards on lending and output, Economic Policy Review, Federal Reserve Bank of New York Jul, 1-16.

Moore, Goeffrey H., 1980, Business Cycles, Inflation and Forecasting, National Bureau of Economic Research Studies in Business Cycles, No. 24, Ballinger Publishing Company.

Myers, Stewart C., 1977, Determinants of Corporate Borrowing, Journal of Financial Economics, 5, 147176.

Passov, Richard, 2003, How Much Cash Does your Company Need?, Harvard Business Review, November, 1-8.

Santos, Joao, A.C., and Andrew Winton, 2008, Bank Loans, Bonds, and Information Monopolies across the Business Cycle, Journal of Finance 63, 1315-1359.

Smith, Clifford and Jerold Warner, 1979, On Financial Contracting: An Analysis of Bond Covenants, Journal of Financial Economics, 7, 117-161.

Stein, Jeremy, 1992, Convertible Bonds as Backdoor Equity Financing, Journal of Financial Economics, 32, 3-21. 
Stulz, Rene M. and Herb Johnson, 1985, An Analysis of Secured Debt, Journal of Financial Economics, 14, 501-521.

Vayanos, Dimitri, 2004, Flight to Quality, Flight to Liquidity, and the Pricing of Risk, NBER Working Paper 10327.

Zhang, Zhipeng, 2008, Recovery Rates and Macroeconomic Conditions: The Role of Loan Covenants, Working Paper. 
Table I

Sample Descriptive Statistics

The sample includes all SEOs, convertible bonds, other public debt, private loans, and private placements of equity and debt issued by US industrial firms that have corresponding accounting information in Compustat as of the fiscal year-end immediately prior to the issue. Sample period is between 1971 and 2007, except for private loans (1988 to 2007) and private placements (1981 to 2007). We divide the sample into six expansion periods and five recession periods based on the NBER classification. For each sub-period, we report the averages of proceeds raised per month in constant 2000 \$US for each of the six security types.

\begin{tabular}{|c|c|c|c|c|c|c|}
\hline & \multicolumn{6}{|c|}{ Average Proceeds per Month (constant 2000 \$US mil) } \\
\hline & \multirow[t]{2}{*}{ SEOs } & \multirow[t]{2}{*}{ Convertibles } & \multirow[t]{2}{*}{ Public Bonds } & \multirow[t]{2}{*}{ Private Loans } & \multicolumn{2}{|c|}{ Private Placements } \\
\hline & & & & & Equity & Debt \\
\hline January 1971-October 1973 & 395.3 & 29.5 & 936.1 & - & - & - \\
\hline November 1973-March 1975 (recession) & 137.2 & 16.9 & $1,632.1$ & - & - & - \\
\hline April 1975-December 1979 & 308.0 & 35.8 & $1,096.3$ & - & - & - \\
\hline January 1980-July 1980 (recession) & 393.1 & 42.0 & $2,937.7$ & - & - & - \\
\hline August 1980-June 1981 & $1,085.1$ & 141.3 & $1,626.2$ & - & 55.3 & 477.3 \\
\hline July 1981-November 1982 (recession) & 413.6 & 76.7 & $1,498.2$ & - & 22.6 & 526.4 \\
\hline December 1982-June 1990 & 710.9 & 477.6 & $3,965.5$ & $11,915.9$ & 194.1 & $2,584.9$ \\
\hline July 1990-March 1991(recession) & 391.9 & 955.3 & 4,000.6 & 7,504.1 & 180.9 & $2,167.5$ \\
\hline April 1991-February 2001 & $2,090.5$ & $1,984.5$ & $16,451.4$ & $28,078.9$ & 221.7 & 815.0 \\
\hline March 2001-November 2001(recession) & $1,677.9$ & $8,264.4$ & $35,598.8$ & $48,832.1$ & 503.2 & 766.8 \\
\hline December 2001-December 2007 & $1,680.4$ & $4,948.9$ & $19,623.0$ & $38,876.3$ & 532.3 & 569.1 \\
\hline All & 844.0 & $1,543.0$ & $8,124.2$ & $12,291.6$ & 155.5 & 718.8 \\
\hline
\end{tabular}


Table II

Macroeconomic Conditions and Security Issues

This table presents the averages of relative proportions of proceeds raised through six types of securities within each calendar month. The sample includes all SEOs, convertible bonds, other public debt, private loans, and private placements of both equity and debt issued by US industrial firms that have corresponding accounting information in Compustat as of the fiscal year-end immediately prior to the issue. Sample period is between 1971 and 2007 for SEOs, convertibles, and other public bonds, 1988 to 2007 for private loans, and 1981 to 2007 for private placements. Expansions and recessions are based on the NBER classification. A month is defined as low growth if GDP growth in that particular quarter is below the $25^{\text {th }}$ percentile of economic growth over the entire sample period. A month with weak credit supply takes a value of one if the net percentage of senior loan officers tightening standards for loans to large and medium firms is positive for that particular quarter. This classification is based on a Federal Reserve survey available since the $2^{\text {nd }}$ quarter of 1990 . For each calendar month, we first calculate the relative proportions of each of the six security types within that month. Panel A reports the monthly averages between 1971 to 1987 where private placements are treated as missing prior to 1981, while panel B reports the corresponding numbers from 1988 to 2007, respectively.

Panel A: 1971 to 1987

\begin{tabular}{|c|c|c|c|c|c|c|}
\hline & \multirow{3}{*}{$\begin{array}{c}\text { Number of } \\
\text { months }\end{array}$} & \multicolumn{5}{|c|}{ Averages of Relative Proceeds within Month (\%) } \\
\hline & & \multirow[t]{2}{*}{ SEOs } & \multirow[t]{2}{*}{ Convertibles } & \multirow[t]{2}{*}{ Public Bonds } & \multicolumn{2}{|c|}{ Private Placements } \\
\hline & & & & & Equity & Debt \\
\hline Expansion & 162 & $23.4 \%$ & $3.4 \%$ & $63.1 \%$ & $1.9 \%$ & $22.7 \%$ \\
\hline Recession & 41 & $15.2 \%$ & $2.1 \%$ & $70.5 \%$ & $1.9 \%$ & $27.4 \%$ \\
\hline t-stat(difference) & & -2.22 & -1.32 & 1.66 & 0.03 & 0.92 \\
\hline High GDP growth & 144 & $22.7 \%$ & $3.6 \%$ & $61.5 \%$ & $1.8 \%$ & $23.5 \%$ \\
\hline Low GDP growth & 59 & $19.3 \%$ & $2.1 \%$ & $71.9 \%$ & $2.2 \%$ & $24.0 \%$ \\
\hline t-stat(difference) & & -1.06 & -1.58 & 2.64 & 0.27 & 0.08 \\
\hline
\end{tabular}

Panel B: 1988 to 2007

\begin{tabular}{lccccccc}
\hline & $\begin{array}{c}\text { Number of } \\
\text { months }\end{array}$ & SEOs & Convertibles Public Bonds Private Loans & \multicolumn{2}{c}{ Private Placements } \\
\cline { 3 - 8 } & & & & & & Equity & Debt \\
\hline Expansion & 222 & $3.8 \%$ & $5.1 \%$ & $28.5 \%$ & $58.0 \%$ & $0.7 \%$ & $3.9 \%$ \\
Recession & 18 & $2.2 \%$ & $7.6 \%$ & $31.9 \%$ & $49.4 \%$ & $1.0 \%$ & $7.8 \%$ \\
$\quad$ t-stat(difference) & & -1.91 & 2.27 & 1.05 & -2.22 & 1.10 & 2.25 \\
& & & & & & & \\
High GDP growth & 180 & $3.9 \%$ & $5.0 \%$ & $28.6 \%$ & $57.8 \%$ & $0.7 \%$ & $4.0 \%$ \\
Low GDP growth & 60 & $3.1 \%$ & $5.9 \%$ & $29.4 \%$ & $55.9 \%$ & $0.9 \%$ & $4.8 \%$ \\
$\quad$ t-stat(difference) & & -1.71 & 1.25 & 0.39 & -0.79 & 1.68 & 0.81 \\
& & & & & & & \\
Strong Credit Supply & 108 & $3.8 \%$ & $4.0 \%$ & $26.0 \%$ & $64.1 \%$ & $0.5 \%$ & $1.6 \%$ \\
Weak Credit Supply & 105 & $4.1 \%$ & $7.0 \%$ & $33.4 \%$ & $51.3 \%$ & $0.8 \%$ & $3.3 \%$ \\
$\quad$ t-stat(difference) & & 0.69 & 5.09 & 4.16 & -6.54 & 3.85 & 3.18 \\
\hline
\end{tabular}


Table III

Macroeconomic Conditions and Types of Public Debt Issues

This table presents the averages of relative proportions of proceeds raised through public debt issues with various characteristics. Short-term months are those firm-months with proceeds-weighted initial maturities shorter than or equal to 5 years. Short-term debts are only available since 1985. Secured months are those firm-months with proceeds-weighted issue-level secured dummy greater than or equal to 0.5 . We group all public debt into five categories based on credit ratings from Moody's; not rated, C's(C to Caa1), speculative B's (B3 to Ba1), investable B's (Baa3 to Baa1), and A's (A3 to Aaa). Expansions and recessions are based on the NBER classification. A month is defined as low growth if GDP growth in that particular quarter is below the $25^{\text {th }}$ percentile of economic growth over the entire sample period. A month is defined as with weak credit supply if the net percentage of senior loan officers tightening standards for loans to large and medium firms is positive for that particular quarter, and is based on Federal Reserve survey. For each calendar month, we first calculate the relative proportions of each of the bond types out of total proceeds raised from public debt within that month. Panel A reports the monthly averages for the full sample period, while panel B reports the monthly averages since the $2^{\text {nd }}$ quarter of 1990 , when the Federal Reserve survey became available.

Panel A: Full Sample Period

\begin{tabular}{|c|c|c|c|c|c|c|c|c|}
\hline & Number of & & & & Averages of Rel & lative Proceeds wi & ithin Month (\%) & \\
\hline & & Short term & Secured & Non Rated & C's(C to Caa1) & Speculative B's & Investable B's & A's (A3 to Aaa) \\
\hline Expansion & 381 & $13.2 \%$ & $5.3 \%$ & $6.2 \%$ & $3.7 \%$ & $25.8 \%$ & $18.7 \%$ & $45.6 \%$ \\
\hline Recession & 58 & $22.9 \%$ & $4.8 \%$ & $2.7 \%$ & $1.2 \%$ & $14.4 \%$ & $15.7 \%$ & $66.0 \%$ \\
\hline t-stat(difference) & & 2.80 & -0.24 & -2.12 & -2.57 & -3.97 & -1.35 & 5.70 \\
\hline High GDP growth & 321 & $13.1 \%$ & $4.6 \%$ & $6.5 \%$ & $3.8 \%$ & $26.2 \%$ & $18.6 \%$ & $45.0 \%$ \\
\hline Low GDP growth & 118 & $16.3 \%$ & $6.8 \%$ & $3.8 \%$ & $2.4 \%$ & $19.0 \%$ & $17.7 \%$ & $57.2 \%$ \\
\hline t-stat(difference) & & 1.53 & 1.65 & -2.09 & -1.88 & -3.31 & -0.52 & 4.40 \\
\hline
\end{tabular}

Panel B: 1990 2nd Quarter to Dec. 2007

\begin{tabular}{|c|c|c|c|c|c|c|c|c|}
\hline & Number of & & & & Averages of Rel & ative Proceeds wi & ithin Month (\%) & \\
\hline & & Short term & Secured & Non Rated & $\mathrm{C}^{\prime} \mathrm{s}(\mathrm{C}$ to $\mathrm{Caa} 1)$ & Speculative B's & Investable B's & A's (A3 to Aaa) \\
\hline Expansion & 195 & $14.3 \%$ & $3.9 \%$ & $3.1 \%$ & $2.8 \%$ & $32.8 \%$ & $23.2 \%$ & $38.0 \%$ \\
\hline Recession & 18 & $22.9 \%$ & $0.7 \%$ & $1.2 \%$ & $0.5 \%$ & $14.5 \%$ & $26.8 \%$ & $56.9 \%$ \\
\hline t-stat(difference) & & 2.45 & -3.01 & -1.87 & -2.60 & -4.76 & 1.12 & 3.96 \\
\hline High GDP growth & 156 & $14.2 \%$ & $4.0 \%$ & $3.2 \%$ & $2.8 \%$ & $34.2 \%$ & $22.6 \%$ & $37.2 \%$ \\
\hline Low GDP growth & 57 & $17.1 \%$ & $2.7 \%$ & $2.3 \%$ & $2.1 \%$ & $23.2 \%$ & $26.1 \%$ & $46.3 \%$ \\
\hline t-stat(difference) & & 1.28 & -1.85 & -1.51 & -1.35 & -4.51 & 1.74 & 3.02 \\
\hline Strong Credit Supply & 108 & $11.2 \%$ & $3.8 \%$ & $3.6 \%$ & $3.4 \%$ & $36.4 \%$ & $22.8 \%$ & $33.7 \%$ \\
\hline Weak Credit Supply & 105 & $18.9 \%$ & $3.5 \%$ & $2.3 \%$ & $1.8 \%$ & $25.9 \%$ & $24.3 \%$ & $45.7 \%$ \\
\hline t-stat(difference) & & 3.98 & -0.61 & -2.35 & -3.41 & -4.94 & 0.87 & 4.54 \\
\hline
\end{tabular}


Table IV

Firm Characteristics by Security Issues: Univariate Analysis

This table presents the averages of firm characteristics for each non-issuing months as well as issuing months over the entire sample period. We also report the results separately for six security types. These characteristics are natural logarithm of the total assets, market leverage, market to book, cash flow, cash, the inverse of interest coverage, a debt-rating dummy, sales growth, and the stock return. Inverse interest coverage is defined as the natural logarithm of (1+interest/EBIT) and stock return is calculated over the previous twelve months. Detailed definition of each characteristic is provided in the Appendix Table 1. Sample period is between 1971 and 2007 for SEOs, convertibles, and other public bonds, 1988 to 2007 for private loans, and 1981 to 2007 for private placements.

\begin{tabular}{|c|c|c|c|c|c|c|c|c|}
\hline & \multicolumn{8}{|c|}{ Averages per Firm-Months Observations } \\
\hline & \multirow[t]{2}{*}{ No Issue } & \multirow[t]{2}{*}{ Issue } & \multirow[t]{2}{*}{ SEOs } & \multirow[t]{2}{*}{ CBs } & \multirow[t]{2}{*}{ Bonds } & \multirow[t]{2}{*}{ Loans } & \multicolumn{2}{|c|}{ Private Placements } \\
\hline & & & & & & & Equity & Debt \\
\hline Firm Age & 13.283 & 16.229 & 9.862 & 15.963 & 21.997 & 16.289 & 9.804 & 17.932 \\
\hline Log(Total Assets) & 4.541 & 5.700 & 4.337 & 6.076 & 7.520 & 5.492 & 3.214 & 6.390 \\
\hline Leverage & 0.278 & 0.323 & 0.278 & 0.305 & 0.395 & 0.321 & 0.247 & 0.331 \\
\hline Market to Book & 1.711 & 1.751 & 2.468 & 2.199 & 1.261 & 1.443 & 3.860 & 1.356 \\
\hline Fixed Asset Ratio & 0.308 & 0.344 & 0.316 & 0.275 & 0.429 & 0.322 & 0.242 & 0.419 \\
\hline Cash Flow & -0.028 & -0.002 & -0.010 & 0.014 & 0.070 & 0.036 & -0.507 & 0.017 \\
\hline Cash & 0.155 & 0.120 & 0.187 & 0.209 & 0.059 & 0.093 & 0.324 & 0.078 \\
\hline Inverse Interest Coverage & 0.182 & 0.235 & 0.183 & 0.155 & 0.306 & 0.245 & 0.039 & 0.300 \\
\hline Rated Firm Dummy & 0.164 & 0.439 & 0.163 & 0.547 & 0.834 & 0.409 & 0.087 & 0.394 \\
\hline Sales Growth & 0.180 & 0.268 & 0.500 & 0.362 & 0.191 & 0.232 & 0.299 & 0.186 \\
\hline Stock Return & 0.174 & 0.357 & 0.970 & 0.582 & 0.221 & 0.193 & 0.416 & 0.174 \\
\hline Term Spread & 1.065 & 1.214 & 1.158 & 1.325 & 1.242 & 1.186 & 1.402 & 1.221 \\
\hline Recession Dummy & 0.109 & 0.078 & 0.074 & 0.078 & 0.087 & 0.068 & 0.081 & 0.108 \\
\hline Low Growth Dummy & 0.248 & 0.215 & 0.194 & 0.222 & 0.215 & 0.213 & 0.258 & 0.223 \\
\hline Weak Credit Dummy & 0.490 & 0.472 & 0.437 & 0.526 & 0.482 & 0.464 & 0.518 & 0.489 \\
\hline $\mathrm{N}$ & $1,585,431$ & 45,980 & 7,170 & 2,546 & 10,400 & 20,322 & 2,957 & 4,547 \\
\hline
\end{tabular}




\section{Table V}

\section{A Multinomial Logit Model of Security Choice}

This table reports coefficient estimates for a multinomial logit model. The dependent variable includes six different types of security issuance: bank loan, public bond, convertible debt, SEO, and private placements of equity and debt. The base outcome is not issuing any type of security. Variables are defined in Appendix Table 1. The sample period is from 1988 to 2007. Panel A is for all firms; Panel B is for noninvestment-grade firms only; and Panel $\mathrm{C}$ is for investment grade firms only. We define noninvestment-grade firms as those that never issued an investment-grade public bond during the entire sample period based on Moody's ratings.All regressions, except for the ones in Panel C, include industry fixed effects. Standard errors, corrected for clustering of observations at the firm level, are in parentheses. The symbols ***,** and * indicate statistical significance at the 1,5 , and $10 \%$ levels, respectively.

Panel A: All Firms

\begin{tabular}{|c|c|c|c|c|c|c|c|c|c|c|c|c|}
\hline & \multicolumn{6}{|c|}{ (1) } & \multicolumn{6}{|c|}{ (2) } \\
\hline & & & & & Private $\mathrm{P}$ & lacements & & & & & Private $\mathrm{F}$ & lacements \\
\hline & Loan & Bond & Convert & SEO & Equity & Debt & Loan & Bond & Convert & SEO & Equity & Debt \\
\hline Firm Age & $\begin{array}{c}-0.00351^{* * *} \\
(0.00111)\end{array}$ & $\begin{array}{c}0.00773^{* * *} \\
(0.00229)\end{array}$ & $\begin{array}{c}-0.0188^{* * *} \\
(0.00386)\end{array}$ & $\begin{array}{c}-0.0444 * * * \\
(0.00288)\end{array}$ & $\begin{array}{c}-0.0196^{* * *} \\
(0.00409)\end{array}$ & $\begin{array}{c}-0.00853^{* * *} \\
(0.00273)\end{array}$ & $\begin{array}{c}-0.00342 * * * \\
(0.00111)\end{array}$ & $\begin{array}{c}0.00773 * * * \\
(0.00230)\end{array}$ & $\begin{array}{c}-0.0189 * * * \\
(0.00387)\end{array}$ & $\begin{array}{c}-0.0441^{* * *} \\
(0.00288)\end{array}$ & $\begin{array}{c}-0.0199 * * * \\
(0.00409)\end{array}$ & $\begin{array}{c}-0.00860^{* * *} \\
(0.00272)\end{array}$ \\
\hline ln(Total Assets) & $\begin{array}{l}0.137 * * * \\
(0.00977)\end{array}$ & $\begin{array}{c}0.365^{* * *} \\
(0.0260)\end{array}$ & $\begin{array}{c}0.316 * * * \\
(0.0268)\end{array}$ & $\begin{array}{c}0.0329 * * \\
(0.0135)\end{array}$ & $\begin{array}{c}-0.168 * * * \\
(0.0246)\end{array}$ & $\begin{array}{c}0.409^{* * *} \\
(0.0196)\end{array}$ & $\begin{array}{l}0.138^{* * *} \\
(0.00978)\end{array}$ & $\begin{array}{c}0.366^{* * *} \\
(0.0259)\end{array}$ & $\begin{array}{c}0.316^{* * *} \\
(0.0268)\end{array}$ & $\begin{array}{c}0.0344^{* *} \\
(0.0135)\end{array}$ & $\begin{array}{c}-0.170^{* * *} \\
(0.0246)\end{array}$ & $\begin{array}{c}0.410 * * * \\
(0.0196)\end{array}$ \\
\hline Market Leverage & $\begin{array}{l}-0.122^{* *} \\
(0.0556)\end{array}$ & $\begin{array}{c}0.549^{* * *} \\
(0.161)\end{array}$ & $\begin{array}{l}-0.0301 \\
(0.178)\end{array}$ & $\begin{array}{c}-0.138 \\
(0.0959)\end{array}$ & $\begin{array}{c}0.00635 \\
(0.168)\end{array}$ & $\begin{array}{c}0.141 \\
(0.144)\end{array}$ & $\begin{array}{c}-0.116^{* *} \\
(0.0556)\end{array}$ & $\begin{array}{c}0.566 * * * \\
(0.161)\end{array}$ & $\begin{array}{c}-0.0186 \\
(0.178)\end{array}$ & $\begin{array}{c}-0.141 \\
(0.0960)\end{array}$ & $\begin{array}{l}0.0112 \\
(0.168)\end{array}$ & $\begin{array}{c}0.166 \\
(0.144)\end{array}$ \\
\hline Market-to-Book & $\begin{array}{c}0.00476 \\
(0.00749)\end{array}$ & $\begin{array}{c}0.0972 * * * \\
(0.0224)\end{array}$ & $\begin{array}{l}0.00993 \\
(0.0131)\end{array}$ & $\begin{array}{c}0.0567 * * * \\
(0.00701)\end{array}$ & $\begin{array}{l}-0.0104 \\
(0.0101)\end{array}$ & $\begin{array}{c}0.000887 \\
(0.0200)\end{array}$ & $\begin{array}{c}0.00503 \\
(0.00751)\end{array}$ & $\begin{array}{c}0.0991 * * * \\
(0.0224)\end{array}$ & $\begin{array}{c}0.0108 \\
(0.0131)\end{array}$ & $\begin{array}{c}0.0574 * * * \\
(0.00700)\end{array}$ & $\begin{array}{l}-0.0100 \\
(0.0101)\end{array}$ & $\begin{array}{l}0.00248 \\
(0.0201)\end{array}$ \\
\hline Fixed-Assets Ratio & $\begin{array}{c}-0.414^{* * *} \\
(0.0696)\end{array}$ & $\begin{array}{c}0.571^{* * *} \\
(0.173)\end{array}$ & $\begin{array}{c}-0.762 * * * \\
(0.235)\end{array}$ & $\begin{array}{l}0.237^{*} \\
(0.121)\end{array}$ & $\begin{array}{c}0.116 \\
(0.224)\end{array}$ & $\begin{array}{c}0.888 * * * \\
(0.166)\end{array}$ & $\begin{array}{c}-0.420^{* * *} \\
(0.0696)\end{array}$ & $\begin{array}{c}0.563 * * * \\
(0.172)\end{array}$ & $\begin{array}{c}-0.760 * * * \\
(0.235)\end{array}$ & $\begin{array}{l}0.233^{*} \\
(0.121)\end{array}$ & $\begin{array}{c}0.124 \\
(0.224)\end{array}$ & $\begin{array}{c}0.882 * * * \\
(0.166)\end{array}$ \\
\hline Cash Flow & $\begin{array}{c}0.392 * * * \\
(0.0743)\end{array}$ & $\begin{array}{l}0.0368 \\
(0.237)\end{array}$ & $\begin{array}{c}-0.0663 \\
(0.124)\end{array}$ & $\begin{array}{l}0.152 * * \\
(0.0679)\end{array}$ & $\begin{array}{c}-0.954^{* * *} \\
(0.0474)\end{array}$ & $\begin{array}{c}-0.827^{* * *} \\
(0.0867)\end{array}$ & $\begin{array}{c}0.391 * * * \\
(0.0743)\end{array}$ & $\begin{array}{l}0.0467 \\
(0.239)\end{array}$ & $\begin{array}{l}-0.0614 \\
(0.124)\end{array}$ & $\begin{array}{l}0.148^{* *} \\
(0.0679)\end{array}$ & $\begin{array}{c}-0.948^{* * *} \\
(0.0475)\end{array}$ & $\begin{array}{c}-0.830 * * * \\
(0.0872)\end{array}$ \\
\hline Cash & $\begin{array}{c}-2.314 * * * \\
(0.0945)\end{array}$ & $\begin{array}{c}-2.855^{* * *} \\
(0.426)\end{array}$ & $\begin{array}{c}1.066^{* * *} \\
(0.192)\end{array}$ & $\begin{array}{l}-0.0342 \\
(0.109)\end{array}$ & $\begin{array}{c}0.586 * * * \\
(0.151)\end{array}$ & $\begin{array}{c}-2.182 * * * \\
(0.264)\end{array}$ & $\begin{array}{c}-2.308 * * * \\
(0.0944)\end{array}$ & $\begin{array}{c}-2.851^{* * *} \\
(0.426)\end{array}$ & $\begin{array}{c}1.064 * * * \\
(0.193)\end{array}$ & $\begin{array}{l}-0.0309 \\
(0.109)\end{array}$ & $\begin{array}{c}0.582 * * * \\
(0.151)\end{array}$ & $\begin{array}{c}-2.189 * * * \\
(0.264)\end{array}$ \\
\hline Inverse Interest Coverage & $\begin{array}{c}0.0132 \\
(0.0189)\end{array}$ & $\begin{array}{l}-0.0667 \\
(0.0430)\end{array}$ & $\begin{array}{c}-0.174^{* *} \\
(0.0697)\end{array}$ & $\begin{array}{l}0.112 * * * \\
(0.0405)\end{array}$ & $\begin{array}{c}-0.122^{* *} \\
(0.0480)\end{array}$ & $\begin{array}{l}0.0790^{*} \\
(0.0459)\end{array}$ & $\begin{array}{c}0.0129 \\
(0.0189)\end{array}$ & $\begin{array}{l}-0.0676 \\
(0.0431)\end{array}$ & $\begin{array}{c}-0.175^{* *} \\
(0.0701)\end{array}$ & $\begin{array}{c}0.112 * * * \\
(0.0405)\end{array}$ & $\begin{array}{c}-0.122^{* *} \\
(0.0479)\end{array}$ & $\begin{array}{l}0.0787^{*} \\
(0.0460)\end{array}$ \\
\hline Debt Rating Dummy & $\begin{array}{c}0.349 * * * \\
(0.0306)\end{array}$ & $\begin{array}{c}2.742 * * * \\
(0.111)\end{array}$ & $\begin{array}{c}1.087^{* * *} \\
(0.119)\end{array}$ & $\begin{array}{l}0.150^{* *} \\
(0.0596)\end{array}$ & $\begin{array}{c}-0.268^{* *} \\
(0.128)\end{array}$ & $\begin{array}{c}-0.435 * * * \\
(0.0879)\end{array}$ & $\begin{array}{c}0.347 * * * \\
(0.0306)\end{array}$ & $\begin{array}{c}2.739 * * * \\
(0.111)\end{array}$ & $\begin{array}{c}1.085^{* * *} \\
(0.119)\end{array}$ & $\begin{array}{l}0.149 * * \\
(0.0596)\end{array}$ & $\begin{array}{c}-0.264^{* *} \\
(0.128)\end{array}$ & $\begin{array}{c}-0.438 * * * \\
(0.0879)\end{array}$ \\
\hline Sales Growth & $\begin{array}{c}0.306^{* * *} \\
(0.0156)\end{array}$ & $\begin{array}{c}0.573 * * * \\
(0.0423)\end{array}$ & $\begin{array}{c}0.316^{* * *} \\
(0.0343)\end{array}$ & $\begin{array}{c}0.375 * * * \\
(0.0175)\end{array}$ & $\begin{array}{c}0.106 * * * \\
(0.0341)\end{array}$ & $\begin{array}{c}0.325 * * * \\
(0.0407)\end{array}$ & $\begin{array}{c}0.305 * * * \\
(0.0156)\end{array}$ & $\begin{array}{c}0.570 * * * \\
(0.0422)\end{array}$ & $\begin{array}{c}0.315^{* * *} \\
(0.0343)\end{array}$ & $\begin{array}{c}0.374 * * * \\
(0.0175)\end{array}$ & $\begin{array}{c}0.106 * * * \\
(0.0341)\end{array}$ & $\begin{array}{c}0.321 * * * \\
(0.0410)\end{array}$ \\
\hline Stock Return & $\begin{array}{c}0.0349 * * * \\
(0.0104)\end{array}$ & $\begin{array}{c}0.162 * * * \\
(0.0205)\end{array}$ & $\begin{array}{c}0.200^{* * *} \\
(0.0213)\end{array}$ & $\begin{array}{c}0.234^{* * *} \\
(0.0128)\end{array}$ & $\begin{array}{c}0.148^{* * *} \\
(0.0141)\end{array}$ & $\begin{array}{l}-0.0114 \\
(0.0416)\end{array}$ & $\begin{array}{c}0.0321 * * * \\
(0.0105)\end{array}$ & $\begin{array}{c}0.156^{* * *} \\
(0.0211)\end{array}$ & $\begin{array}{c}0.198 * * * \\
(0.0214)\end{array}$ & $\begin{array}{c}0.235 * * * \\
(0.0128)\end{array}$ & $\begin{array}{c}0.147 * * * \\
(0.0140)\end{array}$ & $\begin{array}{l}-0.0246 \\
(0.0431)\end{array}$ \\
\hline Term Spread & $\begin{array}{c}0.0111 \\
(0.00695)\end{array}$ & $\begin{array}{c}0.0828 * * * \\
(0.0158)\end{array}$ & $\begin{array}{c}0.172 * * * \\
(0.0266)\end{array}$ & $\begin{array}{c}0.146 * * * \\
(0.0151)\end{array}$ & $\begin{array}{c}0.278^{* * *} \\
(0.0284)\end{array}$ & $\begin{array}{c}0.000944 \\
(0.0229)\end{array}$ & $\begin{array}{c}0.00252 \\
(0.00711)\end{array}$ & $\begin{array}{c}0.0747 * * * \\
(0.0167)\end{array}$ & $\begin{array}{c}0.179 * * * \\
(0.0262)\end{array}$ & $\begin{array}{c}0.131^{* * *} \\
(0.0154)\end{array}$ & $\begin{array}{c}0.293 * * * \\
(0.0280)\end{array}$ & $\begin{array}{l}0.00200 \\
(0.0228)\end{array}$ \\
\hline Recession Dummy & $\begin{array}{l}-0.0371 \\
(0.0293)\end{array}$ & $\begin{array}{c}0.0624 \\
(0.0552)\end{array}$ & $\begin{array}{l}0.203 * * \\
(0.0988)\end{array}$ & $\begin{array}{c}-0.300^{* * * *} \\
(0.0786)\end{array}$ & $\begin{array}{c}0.254 * * * \\
(0.0935)\end{array}$ & $\begin{array}{c}0.275 * * * \\
(0.0770)\end{array}$ & & & & & & \\
\hline Low Growth Dummy & & & & & & & $\begin{array}{c}-0.123^{* * *} \\
(0.0194)\end{array}$ & $\begin{array}{c}-0.130 * * * \\
(0.0371)\end{array}$ & $\begin{array}{c}0.0512 \\
(0.0577)\end{array}$ & $\begin{array}{c}-0.204 * * * \\
(0.0440)\end{array}$ & $\begin{array}{c}0.214^{* * *} \\
(0.0600)\end{array}$ & $\begin{array}{l}-0.0599 \\
(0.0519)\end{array}$ \\
\hline Constant & $\begin{array}{c}-4.159 * * * \\
(0.165) \\
\end{array}$ & $\begin{array}{c}-9.723^{* * *} \\
(0.315) \\
\end{array}$ & $\begin{array}{c}-8.896 * * * \\
(0.680) \\
\end{array}$ & $\begin{array}{c}-5.138^{* * *} \\
(0.335) \\
\end{array}$ & $\begin{array}{c}-7.436 * * * \\
(0.977) \\
\end{array}$ & $\begin{array}{c}-8.911^{* * *} \\
(0.526) \\
\end{array}$ & $\begin{array}{c}-4.128 * * * \\
(0.165) \\
\end{array}$ & $\begin{array}{c}-9.692 * * * \\
(0.315) \\
\end{array}$ & $\begin{array}{c}-8.902 * * * \\
(0.680) \\
\end{array}$ & $\begin{array}{c}-5.103 * * * \\
(0.335) \\
\end{array}$ & $\begin{array}{c}-7.481 * * * \\
(0.976) \\
\end{array}$ & $\begin{array}{c}-8.877^{* * *} \\
(0.526) \\
\end{array}$ \\
\hline Observations & \multicolumn{6}{|c|}{728,639} & \multicolumn{6}{|c|}{728,639} \\
\hline Pseudo R2 & \multicolumn{6}{|c|}{0.093} & \multicolumn{6}{|c|}{0.093} \\
\hline
\end{tabular}


Table V - continued

Panel B: Noninvestment-Grade

Firms

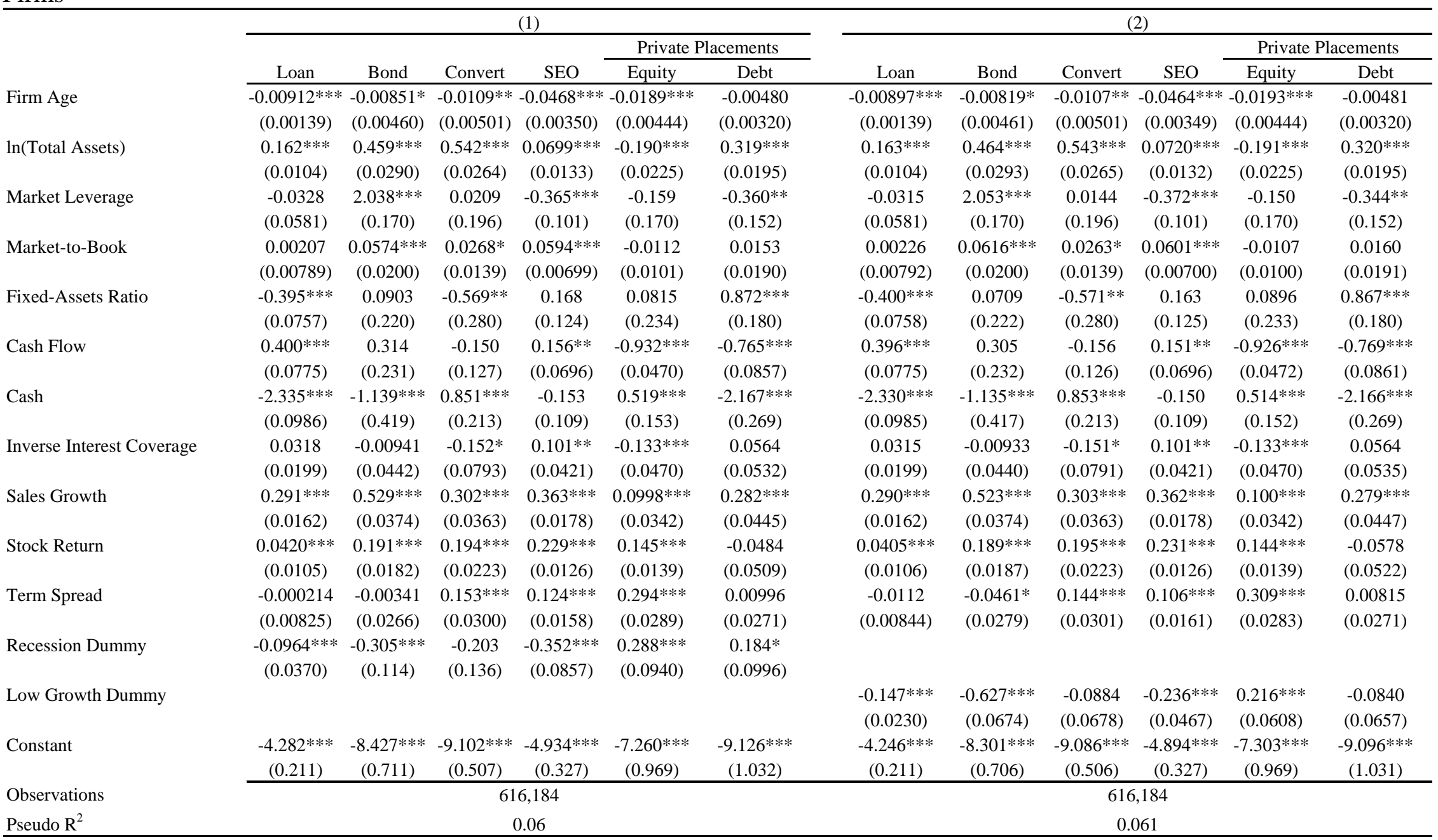


Table V-continued

\section{Panel C: Investment-Grade Firms}

\begin{tabular}{|c|c|c|c|c|c|c|c|c|c|c|c|c|}
\hline & \multicolumn{6}{|c|}{$(1)$} & \multicolumn{6}{|c|}{ (2) } \\
\hline & \multirow[b]{2}{*}{ Loan } & \multirow[b]{2}{*}{ Bond } & \multirow[b]{2}{*}{ Convert } & \multirow[b]{2}{*}{ SEO } & \multicolumn{2}{|c|}{ Private Placements } & \multirow[b]{2}{*}{ Loan } & \multirow[b]{2}{*}{ Bond } & \multirow[b]{2}{*}{ Convert } & \multirow[b]{2}{*}{ SEO } & \multicolumn{2}{|c|}{ Private Placements } \\
\hline & & & & & Equity & Debt & & & & & Equity & Debt \\
\hline Firm Age & $\begin{array}{c}0.00629 * * * \\
(0.00238)\end{array}$ & $\begin{array}{l}0.00546 * \\
(0.00315)\end{array}$ & $\begin{array}{l}-0.00799 \\
(0.00582)\end{array}$ & $\begin{array}{c}-0.0251^{* * *} \\
(0.00571)\end{array}$ & $\begin{array}{c}-0.0385 * * * \\
(0.00946)\end{array}$ & $\begin{array}{c}-0.0170 * * * \\
(0.00457)\end{array}$ & $\begin{array}{c}0.00624 * * * \\
(0.00238)\end{array}$ & $\begin{array}{l}0.00533 * \\
(0.00315)\end{array}$ & $\begin{array}{c}-0.00907 \\
(0.00577)\end{array}$ & $\begin{array}{c}-0.0252 * * * \\
(0.00570)\end{array}$ & $\begin{array}{c}-0.0381^{* * *} \\
(0.00940)\end{array}$ & $\begin{array}{c}-0.0173^{* * *} \\
(0.00454)\end{array}$ \\
\hline $\ln$ (Total Assets) & $\begin{array}{c}0.168^{* * *} \\
(0.0231)\end{array}$ & $\begin{array}{c}0.465^{* * *} \\
(0.0387)\end{array}$ & $\begin{array}{c}0.185^{* * *} \\
(0.0479)\end{array}$ & $\begin{array}{c}-0.155^{* * *} \\
(0.0501)\end{array}$ & $\begin{array}{c}0.343^{* * *} \\
(0.124)\end{array}$ & $\begin{array}{c}0.313^{* * *} \\
(0.0387)\end{array}$ & $\begin{array}{c}0.168^{* * *} \\
(0.0231)\end{array}$ & $\begin{array}{c}0.465^{* * *} \\
(0.0388)\end{array}$ & $\begin{array}{c}0.180^{* * *} \\
(0.0475)\end{array}$ & $\begin{array}{c}-0.155^{* * *} \\
(0.0500)\end{array}$ & $\begin{array}{c}0.346 * * * \\
(0.124)\end{array}$ & $\begin{array}{c}0.311^{* * *} \\
(0.0389)\end{array}$ \\
\hline Market Leverage & $\begin{array}{c}0.187 \\
(0.159)\end{array}$ & $\begin{array}{c}0.682^{* *} \\
(0.295)\end{array}$ & $\begin{array}{c}0.384 \\
(0.456)\end{array}$ & $\begin{array}{c}1.403^{* * *} \\
(0.364)\end{array}$ & $\begin{array}{c}1.405 \\
(1.031)\end{array}$ & $\begin{array}{c}1.572^{* * *} \\
(0.357)\end{array}$ & $\begin{array}{c}0.204 \\
(0.159)\end{array}$ & $\begin{array}{c}0.689 * * \\
(0.294)\end{array}$ & $\begin{array}{c}0.489 \\
(0.452)\end{array}$ & $\begin{array}{c}1.411 * * * \\
(0.364)\end{array}$ & $\begin{array}{c}1.357 \\
(1.027)\end{array}$ & $\begin{array}{c}1.622^{* * *} \\
(0.354)\end{array}$ \\
\hline Market-to-Book & $\begin{array}{l}0.00258 \\
(0.0242)\end{array}$ & $\begin{array}{c}0.113^{* * *} \\
(0.0316)\end{array}$ & $\begin{array}{c}0.0376 \\
(0.0379)\end{array}$ & $\begin{array}{c}-0.0666 \\
(0.0728)\end{array}$ & $\begin{array}{c}-1.117^{* * *} \\
(0.388)\end{array}$ & $\begin{array}{c}-0.365^{* * *} \\
(0.117)\end{array}$ & $\begin{array}{l}0.00368 \\
(0.0242)\end{array}$ & $\begin{array}{c}0.114^{* * *} \\
(0.0315)\end{array}$ & $\begin{array}{c}0.0480 \\
(0.0371)\end{array}$ & $\begin{array}{l}-0.0655 \\
(0.0728)\end{array}$ & $\begin{array}{c}-1.101^{* * *} \\
(0.381)\end{array}$ & $\begin{array}{c}-0.365^{* * *} \\
(0.118)\end{array}$ \\
\hline Fixed-Assets Ratio & $\begin{array}{l}-0.239 * \\
(0.144)\end{array}$ & $\begin{array}{c}0.607^{* * *} \\
(0.182)\end{array}$ & $\begin{array}{l}-0.467 \\
(0.403)\end{array}$ & $\begin{array}{c}1.191 * * * \\
(0.324)\end{array}$ & $\begin{array}{c}1.165^{* *} \\
(0.549)\end{array}$ & $\begin{array}{c}0.600^{* *} \\
(0.282)\end{array}$ & $\begin{array}{l}-0.243^{*} \\
(0.144)\end{array}$ & $\begin{array}{c}0.606 * * * \\
(0.182)\end{array}$ & $\begin{array}{l}-0.478 \\
(0.401)\end{array}$ & $\begin{array}{c}1.187 * * * \\
(0.324)\end{array}$ & $\begin{array}{c}1.207^{* *} \\
(0.545)\end{array}$ & $\begin{array}{c}0.581^{* *} \\
(0.283)\end{array}$ \\
\hline Cash Flow & $\begin{array}{l}-0.184 \\
(0.382)\end{array}$ & $\begin{array}{c}0.535 \\
(0.735)\end{array}$ & $\begin{array}{c}-2.072 * * * \\
(0.594)\end{array}$ & $\begin{array}{c}-2.115^{* * *} \\
(0.614)\end{array}$ & $\begin{array}{c}2.777 \\
(2.447)\end{array}$ & $\begin{array}{c}4.375^{* * *} \\
(1.256)\end{array}$ & $\begin{array}{l}-0.161 \\
(0.384)\end{array}$ & $\begin{array}{c}0.552 \\
(0.735)\end{array}$ & $\begin{array}{c}-1.935^{* * *} \\
(0.587)\end{array}$ & $\begin{array}{c}-2.100 * * * \\
(0.613)\end{array}$ & $\begin{array}{c}2.590 \\
(2.421)\end{array}$ & $\begin{array}{c}4.516^{* * *} \\
(1.251)\end{array}$ \\
\hline Cash & $\begin{array}{c}-1.955^{* * *} \\
(0.325)\end{array}$ & $\begin{array}{c}-4.935^{* * *} \\
(0.661)\end{array}$ & $\begin{array}{c}1.264^{* *} \\
(0.509)\end{array}$ & $\begin{array}{l}0.0375 \\
(0.910)\end{array}$ & $\begin{array}{c}3.031^{* *} \\
(1.372)\end{array}$ & $\begin{array}{c}-2.082 * * * \\
(0.803)\end{array}$ & $\begin{array}{c}-1.954 * * * \\
(0.325)\end{array}$ & $\begin{array}{c}-4.963 * * * \\
(0.660)\end{array}$ & $\begin{array}{c}1.209 * * \\
(0.515)\end{array}$ & $\begin{array}{l}0.0270 \\
(0.911)\end{array}$ & $\begin{array}{c}3.070 * * \\
(1.344)\end{array}$ & $\begin{array}{c}-2.151^{* * *} \\
(0.807)\end{array}$ \\
\hline Inverse Interest Coverage & $\begin{array}{l}-0.0710 \\
(0.0501)\end{array}$ & $\begin{array}{l}-0.0341 \\
(0.0898)\end{array}$ & $\begin{array}{c}-0.372 * * \\
(0.183)\end{array}$ & $\begin{array}{c}0.181 \\
(0.168)\end{array}$ & $\begin{array}{l}0.268^{*} \\
(0.152)\end{array}$ & $\begin{array}{c}0.158 \\
(0.129)\end{array}$ & $\begin{array}{l}-0.0708 \\
(0.0500)\end{array}$ & $\begin{array}{c}-0.0339 \\
(0.0898)\end{array}$ & $\begin{array}{c}-0.375^{* *} \\
(0.178)\end{array}$ & $\begin{array}{c}0.180 \\
(0.168)\end{array}$ & $\begin{array}{l}0.270^{*} \\
(0.154)\end{array}$ & $\begin{array}{c}0.157 \\
(0.126)\end{array}$ \\
\hline Sales Growth & $\begin{array}{c}0.483^{* * *} \\
(0.0714)\end{array}$ & $\begin{array}{c}0.467 * * * \\
(0.0869)\end{array}$ & $\begin{array}{c}0.616^{* * *} \\
(0.178)\end{array}$ & $\begin{array}{c}0.851^{* * *} \\
(0.139)\end{array}$ & $\begin{array}{c}1.078 * * * \\
(0.290)\end{array}$ & $\begin{array}{c}0.566 * * * \\
(0.119)\end{array}$ & $\begin{array}{c}0.478 * * * \\
(0.0710)\end{array}$ & $\begin{array}{c}0.462 * * * \\
(0.0869)\end{array}$ & $\begin{array}{c}0.617 * * * \\
(0.172)\end{array}$ & $\begin{array}{c}0.849 * * * \\
(0.140)\end{array}$ & $\begin{array}{c}1.106^{* * * *} \\
(0.287)\end{array}$ & $\begin{array}{c}0.546^{* * *} \\
(0.119)\end{array}$ \\
\hline Stock Return & $\begin{array}{c}0.0128 \\
(0.0388)\end{array}$ & $\begin{array}{c}0.0799 \\
(0.0611)\end{array}$ & $\begin{array}{c}0.519 * * * \\
(0.0639)\end{array}$ & $\begin{array}{c}0.595 * * * \\
(0.0618)\end{array}$ & $\begin{array}{c}0.421^{* *} \\
(0.173)\end{array}$ & $\begin{array}{c}0.0786 \\
(0.0948)\end{array}$ & $\begin{array}{l}0.00312 \\
(0.0395)\end{array}$ & $\begin{array}{c}0.0827 \\
(0.0607)\end{array}$ & $\begin{array}{c}0.499 * * * \\
(0.0656)\end{array}$ & $\begin{array}{c}0.595 * * * \\
(0.0621)\end{array}$ & $\begin{array}{c}0.448 * * * \\
(0.166)\end{array}$ & $\begin{array}{c}0.0537 \\
(0.0965)\end{array}$ \\
\hline Term Spread & $\begin{array}{c}0.0286 * * \\
(0.0133)\end{array}$ & $\begin{array}{c}0.0931^{* * *} \\
(0.0202)\end{array}$ & $\begin{array}{c}0.231^{* * *} \\
(0.0553)\end{array}$ & $\begin{array}{c}0.334 * * * \\
(0.0529)\end{array}$ & $\begin{array}{l}-0.168 \\
(0.155)\end{array}$ & $\begin{array}{c}-0.0120 \\
(0.0421)\end{array}$ & $\begin{array}{l}0.0262 * \\
(0.0135)\end{array}$ & $\begin{array}{c}0.100^{* * *} \\
(0.0212)\end{array}$ & $\begin{array}{c}0.267 * * * \\
(0.0516)\end{array}$ & $\begin{array}{c}0.339 * * * \\
(0.0532)\end{array}$ & $\begin{array}{l}-0.170 \\
(0.163)\end{array}$ & $\begin{array}{l}-0.00699 \\
(0.0414)\end{array}$ \\
\hline Recession Dummy & $\begin{array}{c}0.0935 * * \\
(0.0457)\end{array}$ & $\begin{array}{l}0.134^{* *} \\
(0.0648)\end{array}$ & $\begin{array}{c}1.030^{* * *} \\
(0.149)\end{array}$ & $\begin{array}{c}0.183 \\
(0.200)\end{array}$ & $\begin{array}{l}-1.320 \\
(1.023)\end{array}$ & $\begin{array}{c}0.405^{* * *} \\
(0.124)\end{array}$ & & & & & & \\
\hline Low Growth Dummy & & & & & & & $\begin{array}{l}-0.0505 \\
(0.0364)\end{array}$ & $\begin{array}{c}0.0758^{*} \\
(0.0430)\end{array}$ & $\begin{array}{c}0.453^{* * *} \\
(0.113)\end{array}$ & $\begin{array}{c}0.105 \\
(0.134)\end{array}$ & $\begin{array}{c}0.157 \\
(0.352)\end{array}$ & $\begin{array}{l}-0.0160 \\
(0.0850)\end{array}$ \\
\hline Constant & $\begin{array}{c}-4.582 * * * \\
(0.193)\end{array}$ & $\begin{array}{c}-7.547 * * * \\
(0.321)\end{array}$ & $\begin{array}{c}-7.155^{* * *} \\
(0.429)\end{array}$ & $\begin{array}{c}-5.425^{* * *} \\
(0.467)\end{array}$ & $\begin{array}{c}-9.428^{* * *} \\
(1.133)\end{array}$ & $\begin{array}{c}-7.509 * * * \\
(0.365)\end{array}$ & $\begin{array}{c}-4.563^{* * * *} \\
(0.193)\end{array}$ & $\begin{array}{c}-7.559 * * * \\
(0.322)\end{array}$ & $\begin{array}{c}-7.180^{* * *} \\
(0.421)\end{array}$ & $\begin{array}{c}-5.438 * * * \\
(0.465)\end{array}$ & $\begin{array}{c}-9.573 * * * \\
(1.155)\end{array}$ & $\begin{array}{c}-7.464 * * * \\
(0.367)\end{array}$ \\
\hline Observations & & & & 12,512 & & & & & 112 & 2,512 & & \\
\hline Pseudo $\mathrm{R}^{2}$ & & & & 0.044 & & & & & & 043 & & \\
\hline
\end{tabular}




\section{Table VI \\ Cash Holdings from Capital Raising Activities}

This table presents the estimation results from the following regression specification:

$$
Y=\beta_{0}+\beta_{1} \ln \left[\left(\frac{\text { capital raised }}{{\text { total } \text { assets }_{0}}}\right)+1\right]+\beta_{2} \ln \left[\left(\frac{\text { capital raised }}{{\text { total } \text { assets }_{0}}_{0}}\right)+1\right] \times \text { RecessionDummy }+\beta_{3} \ln [\text { total assets }]+\varepsilon \text {, }
$$

where $Y=\ln \left[\left(V_{t}-V_{0}\right) /\right.$ total $\left.\left._{\text {assets }}\right)+1\right]$, and $V=$ quarterly cash and short term investments. $t=1,4,8$ corresponds to the fiscal quarter following the issuing quarter. In the first three rows, all new issues regardless of type of security are aggregated within a calendar quarter and these quarters are matched with the NBER's expansion/recession dates. In the remaining row, we estimate the result separately for each of the security types. We report the results separately for noninvestment-grade firms and investment-grade firms. Noninvestment-grade firms are defined as those that never issued an investment grade public bond during the entire sample period.

\begin{tabular}{|c|c|c|c|c|c|c|c|c|c|}
\hline \multirow{3}{*}{$\begin{array}{l}\text { Dependent Variable: } \\
\text { Cash \& } \\
\text { Short-term Investments }\end{array}$} & \multirow[b]{3}{*}{$t$} & \multicolumn{4}{|c|}{ Noninvestment-Grade Firms } & \multicolumn{4}{|c|}{ Investment-Grade Firms } \\
\hline & & \multicolumn{2}{|c|}{$\beta_{1}$} & \multicolumn{2}{|c|}{$\beta_{2}$} & \multicolumn{2}{|c|}{$\beta_{1}$} & \multicolumn{2}{|c|}{$\beta_{2}$} \\
\hline & & Coeff & t-stat & Coeff & t-stat & Coeff & t-stat & Coeff & t-stat \\
\hline \multirow[t]{3}{*}{ All Sources } & $1 \mathrm{Q}$ & 0.381 & 101.48 & -0.077 & -7.14 & 0.089 & 18.42 & -0.015 & -1.17 \\
\hline & $4 \mathrm{Q}$ & 0.324 & 69.01 & -0.064 & -4.70 & 0.069 & 12.43 & 0.050 & 3.30 \\
\hline & $8 \mathrm{Q}$ & 0.285 & 50.45 & -0.086 & -5.36 & 0.084 & 13.61 & 0.079 & 4.66 \\
\hline \multirow[t]{3}{*}{ SEOs } & $1 \mathrm{Q}$ & 0.917 & 103.31 & -0.013 & -0.57 & 0.822 & 28.48 & 0.008 & 0.12 \\
\hline & $4 \mathrm{Q}$ & 0.816 & 66.95 & 0.027 & 0.84 & 0.653 & 14.14 & 0.869 & 8.62 \\
\hline & $8 \mathrm{Q}$ & 0.647 & 38.32 & -0.005 & -0.12 & 0.716 & 14.34 & 0.471 & 4.35 \\
\hline \multirow[t]{3}{*}{ CBs } & $1 \mathrm{Q}$ & 0.637 & 27.15 & 0.152 & 2.83 & 0.275 & 8.44 & -0.101 & -2.16 \\
\hline & $4 \mathrm{Q}$ & 0.568 & 19.35 & 0.029 & 0.42 & 0.187 & 4.85 & -0.055 & -1.00 \\
\hline & $8 \mathrm{Q}$ & 0.525 & 13.93 & -0.139 & -1.60 & 0.168 & 3.20 & -0.061 & -0.82 \\
\hline \multirow[t]{3}{*}{ Bonds } & $1 \mathrm{Q}$ & 0.475 & 38.87 & -0.145 & -3.81 & 0.076 & 11.30 & -0.029 & -2.22 \\
\hline & $4 \mathrm{Q}$ & 0.472 & 36.13 & -0.160 & -3.84 & 0.102 & 10.52 & -0.004 & -0.20 \\
\hline & $8 \mathrm{Q}$ & 0.485 & 29.66 & -0.166 & -3.20 & 0.116 & 9.36 & 0.093 & 3.81 \\
\hline \multirow[t]{3}{*}{ Loans } & $1 \mathrm{Q}$ & 0.097 & 28.64 & -0.057 & -5.41 & 0.087 & 10.41 & -0.019 & -0.69 \\
\hline & $4 \mathrm{Q}$ & 0.072 & 13.94 & -0.054 & -3.40 & 0.053 & 6.25 & 0.022 & 0.80 \\
\hline & $8 \mathrm{Q}$ & 0.074 & 12.06 & -0.075 & -4.06 & 0.062 & 6.74 & 0.030 & 1.01 \\
\hline Private Placements: & $1 \mathrm{Q}$ & 0.688 & 52.52 & -0.187 & -6.35 & 0.378 & 4.18 & -1.239 & -3.98 \\
\hline \multirow[t]{2}{*}{ Equities } & $4 \mathrm{Q}$ & 0.621 & 30.41 & -0.146 & -3.16 & 1.303 & 7.98 & -0.223 & -0.40 \\
\hline & $8 \mathrm{Q}$ & 0.530 & 20.66 & -0.139 & -2.46 & 0.878 & 6.98 & -0.624 & -1.46 \\
\hline Private Placements: & $1 \mathrm{Q}$ & 0.161 & 18.18 & -0.064 & -2.42 & 0.078 & 4.84 & 0.004 & 0.11 \\
\hline \multirow[t]{2}{*}{ Debt } & $4 \mathrm{Q}$ & 0.097 & 8.86 & -0.070 & -2.06 & 0.031 & 1.36 & -0.134 & -2.61 \\
\hline & $8 \mathrm{Q}$ & 0.094 & 6.23 & -0.125 & -2.80 & 0.014 & 0.50 & 0.288 & 4.59 \\
\hline
\end{tabular}




\section{Table VII}

Factors affecting the Maturity and Security of Public Bonds and Bank Loans: Logit Model

This table reports coefficient estimates for a logit model. Panel A includes only public bond issuances and their characteristics from 1985 to 2007 in the first three columns (since there is no short-term bond issue before 1985 in our sample) and from 1971 to 2007 in the last three columns. Panel B includes bank loans only and the sample period is from 1988 to 2007. In columns (3) and (6) of both panels A and B, where we include weak credit dummy, the sample period is from the second quarter of 1990 to 2007. The dependent variable is equal to one if the public debt or bank loan is short-term in columns (1) through (3), or secured in columns (4) through (6). All regressions include industry fixed effects. Standard errors, corrected for clustering of observations at the firm level, are in parentheses. The symbols $* * *, * *$ and * indicate statistical significance at the 1, 5, and 10\% levels, respectively.

Panel A: Public Bond Issues

\begin{tabular}{|c|c|c|c|c|c|c|}
\hline & \multicolumn{3}{|c|}{ Short-term vs. Long-term Bond } & \multicolumn{3}{|c|}{ Secured vs. Unsecured Bond } \\
\hline & (1) & $(2)$ & (3) & (4) & $(5)$ & $(6)$ \\
\hline \multirow[t]{2}{*}{ Firm Age } & $0.0166^{* * *}$ & $0.0159 * * *$ & $0.0183^{* * *}$ & -0.00681 & -0.00666 & 0.00138 \\
\hline & $(0.00489)$ & $(0.00487)$ & $(0.00489)$ & $(0.0124)$ & $(0.0124)$ & $(0.0130)$ \\
\hline \multirow[t]{2}{*}{$\ln$ (Total Assets) } & $0.275^{* * *}$ & $0.275^{* * *}$ & $0.254 * * *$ & $-0.244 * *$ & $-0.263 * * *$ & $-0.543^{* * *}$ \\
\hline & $(0.0396)$ & $(0.0396)$ & $(0.0420)$ & $(0.0972)$ & $(0.102)$ & $(0.120)$ \\
\hline \multirow[t]{2}{*}{ Leverage } & 0.183 & 0.205 & 0.199 & $4.471 * * *$ & $4.482 * * *$ & $4.233^{* * *}$ \\
\hline & $(0.516)$ & $(0.509)$ & $(0.575)$ & $(0.679)$ & $(0.681)$ & $(0.697)$ \\
\hline \multirow[t]{2}{*}{ Market-to-Book } & $0.218 * * *$ & $0.228 * * *$ & $0.186 * * *$ & -0.185 & -0.180 & -0.187 \\
\hline & $(0.0571)$ & $(0.0565)$ & $(0.0621)$ & $(0.270)$ & $(0.263)$ & $(0.243)$ \\
\hline \multirow[t]{2}{*}{ Fixed-Assets Ratio } & $-0.765 * *$ & $-0.772 * *$ & $-0.766 * *$ & $2.987^{* * *}$ & $3.024 * * *$ & 1.126 \\
\hline & $(0.352)$ & $(0.351)$ & $(0.382)$ & $(0.790)$ & $(0.789)$ & $(1.127)$ \\
\hline \multirow[t]{2}{*}{ Cash Flow } & $-1.431 * *$ & $-1.414 * *$ & $-1.302^{*}$ & -0.591 & -0.652 & -0.825 \\
\hline & $(0.668)$ & $(0.658)$ & $(0.680)$ & $(1.131)$ & $(1.099)$ & $(1.124)$ \\
\hline \multirow[t]{2}{*}{ Cash } & $-1.615 *$ & $-1.714^{* *}$ & $-1.524^{*}$ & $2.688^{* *}$ & $2.879 * * *$ & $2.845^{* *}$ \\
\hline & $(0.858)$ & $(0.858)$ & $(0.871)$ & $(1.066)$ & $(1.061)$ & $(1.125)$ \\
\hline \multirow[t]{2}{*}{ Inverse Interest Coverage } & -0.00550 & -0.00796 & 0.00675 & -0.0682 & -0.0761 & 0.00699 \\
\hline & $(0.149)$ & $(0.147)$ & $(0.148)$ & $(0.154)$ & $(0.156)$ & $(0.185)$ \\
\hline \multirow[t]{2}{*}{ Debt Rating Dummy } & -0.343 & -0.335 & $-0.510^{*}$ & -0.270 & -0.178 & 0.363 \\
\hline & $(0.232)$ & $(0.232)$ & $(0.293)$ & $(0.203)$ & $(0.212)$ & $(0.428)$ \\
\hline \multirow[t]{2}{*}{ Sales Growth } & $-0.376 *$ & $-0.390 * *$ & $-0.490 * *$ & 0.160 & 0.159 & 0.228 \\
\hline & $(0.195)$ & $(0.196)$ & $(0.223)$ & $(0.197)$ & $(0.189)$ & $(0.202)$ \\
\hline \multirow[t]{2}{*}{ Stock Return } & $-0.384 * * *$ & $-0.384 * * *$ & $-0.249 * *$ & $-0.566 * * *$ & $-0.527 * * *$ & $-0.562 * * *$ \\
\hline & $(0.139)$ & $(0.139)$ & $(0.125)$ & $(0.138)$ & $(0.134)$ & $(0.149)$ \\
\hline \multirow[t]{2}{*}{ Term Spread } & $-15.38 * * *$ & $-13.55^{* * *}$ & $-13.85^{* * *}$ & 6.016 & 8.957 & 15.94 \\
\hline & $(4.667)$ & $(4.622)$ & (5.038) & (8.991) & (8.753) & $(9.745)$ \\
\hline \multirow[t]{2}{*}{ Recession Dummy } & $0.405^{* * *}$ & & & -0.362 & & \\
\hline & $(0.124)$ & & & $(0.228)$ & & \\
\hline \multirow[t]{2}{*}{ Low Growth Dummy } & & $0.148^{*}$ & & & $0.373 * *$ & \\
\hline & & $(0.0844)$ & & & $(0.157)$ & \\
\hline \multirow[t]{2}{*}{ Weak Credit Dummy } & & & $0.430 * * *$ & & & 0.123 \\
\hline & & & $(0.102)$ & & & $(0.203)$ \\
\hline \multirow[t]{2}{*}{ Constant } & $-3.676 * * *$ & $-3.696 * * *$ & $-3.632 * * *$ & $-4.489 * * *$ & $-4.597 * * *$ & $-2.843 * * *$ \\
\hline & $(0.553)$ & $(0.550)$ & $(0.603)$ & $(1.181)$ & $(1.193)$ & $(1.061)$ \\
\hline Observations & 7,523 & 7,523 & 6,664 & 8,314 & 8,314 & 6,664 \\
\hline Pseudo $\mathrm{R}^{2}$ & 0.111 & 0.110 & 0.120 & 0.250 & 0.251 & 0.287 \\
\hline
\end{tabular}


Table VII - continued

\section{Panel B: Bank Loans}

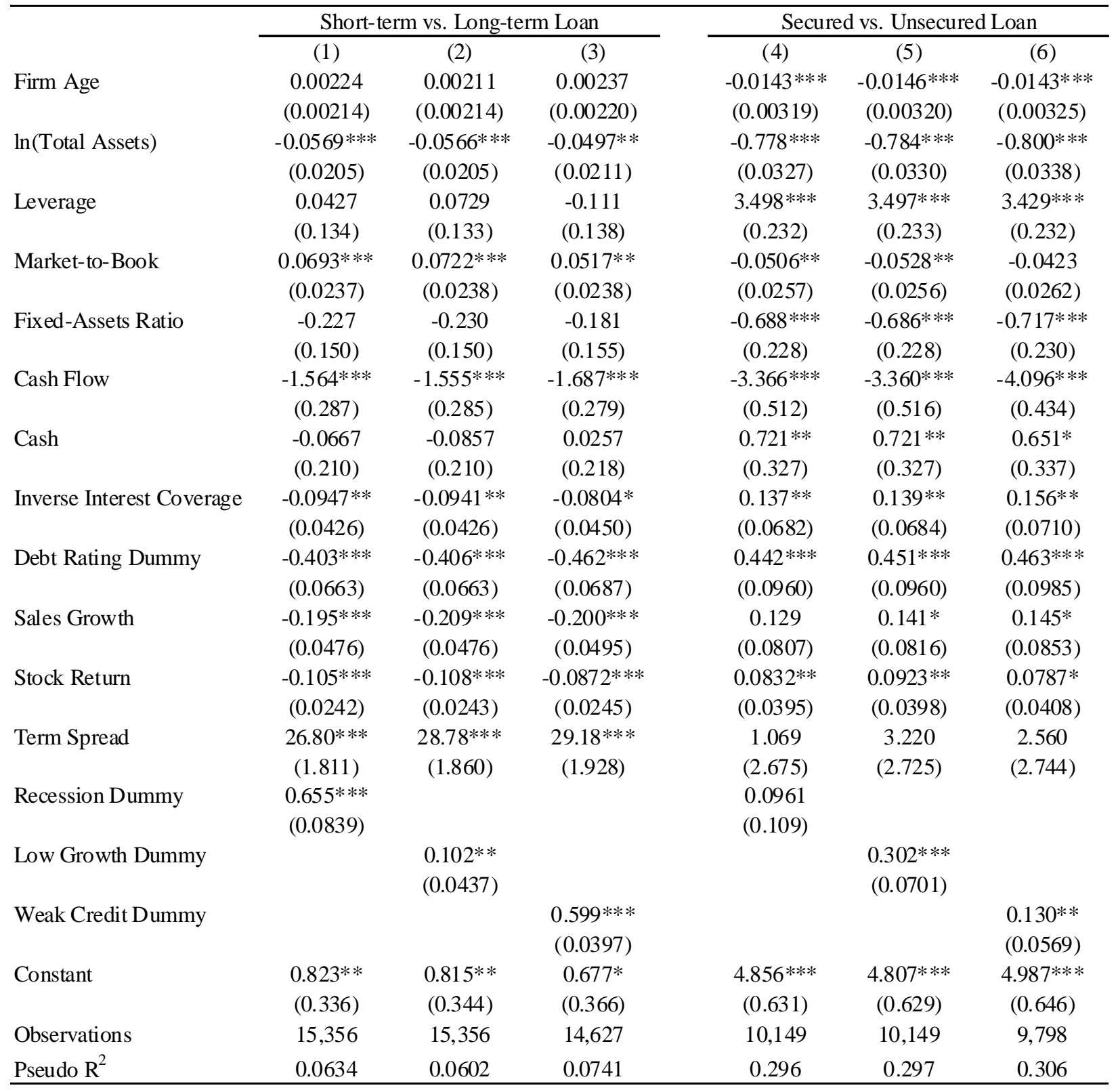




\section{Appendix Table 1}

This data appendix describes the primary variables of interest. All firm characteristics, unless noted otherwise, represent beginning-of-year values. Data sources, included in the last column, include Compustat, CSRP, Loan Pricing Corporation's Dealscan, Mergent Fixed Income Securities Database, SDC Global New Issues Database, US Bureau of Economic Analysis, National Bureau of Economic Research, and the US Federal Reserve Board.

Variable $\quad$ Definition $\quad$ Source

Bond Issuance Proceeds

Bond Maturity Dummy

Bond Security Dummy

Cash

Cash Flow

Convertible Bond Proceeds

Credit Quality

Equity Issuance Proceeds

Financing Choice Variable for the Multinomial and Ordered Logit Models

Fixed Asset Ratio

Inverse Interest Coverage

Loan Maturity Dummy

Loan Proceeds

Loan Security Dummy

Log(Total Assets)
Total proceeds raised through a public bond offering in a given month

Set equal to one if the proceeds-weighted initial maturity of bonds issued in a given month is less than 5 years, zero otherwise

Set equal to one if the proceeds-weighted initial secured bond dummy a given month is greater than 0.5 , zero otherwise

Cash and short-term investments, scaled by total assets Income before extraordinary items plus depreciation, scaled by the book value of total assets

Total proceeds raised through a convertible bond offering in a given month

Obtained from Moody's credit ratings and classified as follows: 0 - not rated, 1 - C to Caa1, 2 - B3 to Ba1, 3 Baa3 to Baa1, 4 - A3 to Aaa

Total proceeds raised through a seasoned equity offering in a given month

Classified as following for each firm-month: 0 - No issue, 1 - Loan, 2 - Bond, 3 - Convertible, 4 - Seasoned equity offering. In months with multiple issues, the classification is determined by the largest issue in terms of proceeds raised

Net property, plant and equipment scaled by the book value of total assets

$\log (1+($ Interest Expense/EBIT $))$

Set equal to one if the proceeds-weighted initial maturity of loans obtained in a given month is less than 5 years, zero otherwise

Total proceeds raised through a bank loan in a given month

Set equal to one if the proceeds-weighted initial secured loan dummy a given month is greater than 0.5 , zero otherwise

Natural logarithm of the book value of assets in constant 1994 dollars
Mergent FISD

Mergent FISD

Mergent FISD

Compustat

Compustat

Mergent FISD

Mergent FISD

SDC Global

Dealscan, Mergent FISD, SDC Global

Compustat

Compustat

Dealscan

Dealscan

Dealscan

Compustat 
Low Growth Dummy

Market leverage

Market to Book

Rated Firm Dummy

Recession Dummy

Sales Growth

Secured Bond Dummy

Secured Loan Dummy

Stock Return

Term Spread

Weak Credit Dummy
Set equal to one in quarters in which GDP growth was

BEA

below the 25th percentile of growth between 1971 and 2007, zero otherwise

Long-term debt plus debt in current liabilities, scaled by the market value of assets (total assets - book value of equity + market value of equity)

Book value of total debt plus the liquidating value of preferred stock plus the market value of equity, scaled by the book value of total assets

Indicator set equal to 1 if a firm has an S\&P domestic long-term issuer credit rating, zero otherwise

Set equal to one in months designated as recession by the NBER

Percentage change in sales over the previous year

Set equal for to one if an issued bond is classified as secured

Set equal for to one if a bank loan is classified as secured

Previous 12-month stock return

Compustat

Compustat

Compustat

NBER

Compustat

Mergent FISD

Dealscan

CRSP

Difference in the yields on ten-year treasuries and oneyear treasuries.

Set equal to one in months when the net percentage of senior loan officers tightening standards for large to medium firms is positive, zero otherwise 


\section{Appendix Table 2}

\section{A Multinomial Logit Model of Security Choice using Weak Credit Dummy for Downturns}

This table reports coefficient estimates for a multinomial logit model as in Table V but using weak credit dummy for downturns. The dependent variable includes six different types of security issuance: bank loan, public bond, convertible debt, SEO, private placements of equity and debt. The base outcome is not issuing any type of security. Variables are defined in Appendix Table 1 . The sample period is from the second quarter of 1990 to 2007. Panel A is for all firms; Panel B is for noninvestment-grade firms only; and Panel C is for investment grade firms only. All regressions, except for the ones in Panel C, include industry FEs. Standard errors, corrected for clustering of observations at the firm level, are in parentheses. The symbols ***, ** and * indicate statistical significance at the 1,5 , and $10 \%$ levels, respectively

\begin{tabular}{|c|c|c|c|c|c|c|c|c|c|c|c|c|c|c|c|c|c|c|}
\hline & \multicolumn{6}{|c|}{ PANEL A } & \multirow{2}{*}{\multicolumn{6}{|c|}{ PANEL B }} & \multirow{2}{*}{\multicolumn{6}{|c|}{ PANEL C }} \\
\hline & & & & & Private $\mathrm{P}$ & lacements & & & & & Private $\mathrm{Pl}$ & cements & & & & & & acements \\
\hline & Loan & Bond & Convert & SEO & Equity & Debt & Loan & Bond & Convert & SEO & Equity & Debt & Loan & Bond & Convert & SEO & Equity & Debt \\
\hline Firm Age & $\begin{array}{c}-0.00400^{* * *} \\
(0.00109)\end{array}$ & $\begin{array}{c}0.00746^{* * *} \\
(0.00227)\end{array}$ & $\begin{array}{c}-0.0188^{* * *} \\
(0.00386)\end{array}$ & $\begin{array}{c}-0.0444 * * * \\
(0.00294)\end{array}$ & $\begin{array}{c}-0.0230 * * * \\
(0.00431)\end{array}$ & $\begin{array}{c}-0.00603^{* *} \\
(0.00296)\end{array}$ & $\begin{array}{c}-0.00956 * * * \\
(0.00139)\end{array}$ & $\begin{array}{l}-0.00821^{*} \\
(0.00450)\end{array}$ & $\begin{array}{l}-0.0113 * * \\
(0.00505)\end{array}$ & $\begin{array}{c}-0.0471 * * * \\
(0.00360)\end{array}$ & $\begin{array}{l}-0.0216 * * * \\
(0.00451)\end{array}$ & $\begin{array}{c}-0.00425 \\
(0.00350)\end{array}$ & $\begin{array}{c}0.00624^{* * * *} \\
(0.00238)\end{array}$ & $\begin{array}{l}0.00533^{*} \\
(0.00315)\end{array}$ & $\begin{array}{c}-0.00907 \\
(0.00577)\end{array}$ & $\begin{array}{c}-0.0252 * * * * \\
(0.00570)\end{array}$ & $\begin{array}{c}-0.0381^{* * *} \\
(0.00940)\end{array}$ & $\begin{array}{c}-0.0173^{* * * *} \\
(0.00454)\end{array}$ \\
\hline In(Total Assets) & $\begin{array}{l}0.137 * * * \\
(0.00986)\end{array}$ & $\begin{array}{l}0.351 * * * \\
(0.0262)\end{array}$ & $\begin{array}{l}0.319^{* * * *} \\
(0.0273)\end{array}$ & $\begin{array}{l}0.0269^{*} \\
(0.0141)\end{array}$ & $\begin{array}{c}-0.228 * * * * \\
(0.0248)\end{array}$ & $\begin{array}{l}0.392 * * * \\
(0.0211)\end{array}$ & $\begin{array}{l}0.157 * * * \\
(0.0104)\end{array}$ & $\begin{array}{l}0.451 * * * \\
(0.0287)\end{array}$ & $\begin{array}{l}0.533^{* * * *} \\
(0.266)\end{array}$ & $\begin{array}{c}0.0627 * * * \\
(0.0138)\end{array}$ & $\begin{array}{c}-0.237 * * * * \\
(0.0226)\end{array}$ & $\begin{array}{l}0.294 * * * \\
(0.0208)\end{array}$ & $\begin{array}{l}0.168 * * * \\
(0.0231)\end{array}$ & $\begin{array}{l}0.466 * * * \\
(0.0388)\end{array}$ & $\begin{array}{l}0.180 * * * * \\
(0.0475)\end{array}$ & $\begin{array}{c}-0.155 * * * \\
(0.0500)\end{array}$ & $\begin{array}{l}0.346 * * * \\
(0.124)\end{array}$ & $\begin{array}{l}0.311 * * * * \\
(0.0389)\end{array}$ \\
\hline Market Leverage & $\begin{array}{l}-0.102^{*} \\
(0.0566)\end{array}$ & $\begin{array}{c}0.583^{* * *} \\
(0.166)\end{array}$ & $\begin{array}{l}0.0317 \\
(0.183)\end{array}$ & $\begin{array}{l}-0.0334 \\
(0.0988)\end{array}$ & $\begin{array}{l}-0.0530 \\
(0.170)\end{array}$ & $\begin{array}{l}-0.205 \\
(0.151)\end{array}$ & $\begin{array}{l}-0.00778 \\
(0.0592)\end{array}$ & $\begin{array}{c}2.135^{* * * *} \\
(0.169)\end{array}$ & $\begin{array}{l}0.0696 \\
(0.201)\end{array}$ & $\begin{array}{c}-0.239^{* *} \\
(0.105)\end{array}$ & $\begin{array}{l}-0.169 \\
(0.171)\end{array}$ & $\begin{array}{c}-0.680^{* * *} \\
(0.164)\end{array}$ & $\begin{array}{c}0.204 \\
(0.159)\end{array}$ & $\begin{array}{l}0.689 * * \\
(0.294)\end{array}$ & $\begin{array}{c}0.489 \\
(0.452)\end{array}$ & $\begin{array}{c}1.411^{* * * *} \\
(0.364)\end{array}$ & $\begin{array}{c}1.357 \\
(1.027)\end{array}$ & $\begin{array}{c}1.622 * * * \\
(0.354)\end{array}$ \\
\hline Market-to-Book & $\begin{array}{l}-0.00184 \\
(0.00781)\end{array}$ & $\begin{array}{c}0.0908^{* * *} \\
(0.0231)\end{array}$ & $\begin{array}{l}0.00429 \\
(0.0134)\end{array}$ & $\begin{array}{l}0.0587 * * * \\
(0.00711)\end{array}$ & $\begin{array}{l}-0.0129 \\
(0.0101)\end{array}$ & $\begin{array}{c}0.0204 \\
(0.0190)\end{array}$ & $\begin{array}{l}-0.00262 \\
(0.00822)\end{array}$ & $\begin{array}{l}0.0514 * * \\
(0.0211)\end{array}$ & $\begin{array}{l}0.0236^{*} \\
(0.0141)\end{array}$ & $\begin{array}{l}0.0618^{* * *} \\
(0.00713)\end{array}$ & $\begin{array}{l}-0.0133 \\
(0.0101)\end{array}$ & $\begin{array}{c}0.0201 \\
(0.0193)\end{array}$ & $\begin{array}{l}0.00368 \\
(0.0242)\end{array}$ & $\begin{array}{l}0.114 * * * \\
(0.0315)\end{array}$ & $\begin{array}{c}0.0480 \\
(0.0371)\end{array}$ & $\begin{array}{l}-0.0655 \\
(0.0728)\end{array}$ & $\begin{array}{c}-1.101 * * * \\
(0.381)\end{array}$ & $\begin{array}{c}-0.365 * * * \\
(0.118)\end{array}$ \\
\hline Fixed-Assets Ratio & $\begin{array}{c}-0.362 * * * \\
(0.0692)\end{array}$ & $\begin{array}{c}0.597 * * * * \\
(0.174)\end{array}$ & $\begin{array}{c}-0.726 * * * \\
(0.241)\end{array}$ & $\begin{array}{l}0.268 * * \\
(0.125)\end{array}$ & $\begin{array}{c}0.125 \\
(0.231)\end{array}$ & $\begin{array}{c}0.788^{* * *} \\
(0.190)\end{array}$ & $\begin{array}{c}-0.366 * * * \\
(0.0751)\end{array}$ & $\begin{array}{c}0.103 \\
(0.217)\end{array}$ & $\begin{array}{l}-0.514^{*} \\
(0.283)\end{array}$ & $\begin{array}{c}0.207 \\
(0.129)\end{array}$ & $\begin{array}{c}0.121 \\
(0.237)\end{array}$ & $\begin{array}{c}0.879 * * * \\
(0.203)\end{array}$ & $\begin{array}{l}-0.243^{*} \\
(0.144)\end{array}$ & $\begin{array}{c}0.606 * * * \\
(0.182)\end{array}$ & $\begin{array}{l}-0.478 \\
(0.401)\end{array}$ & $\begin{array}{c}1.187 * * * \\
(0.324)\end{array}$ & $\begin{array}{l}1.207 * * \\
(0.545)\end{array}$ & $\begin{array}{l}0.581 * * \\
(0.283)\end{array}$ \\
\hline Cash Flow & $\begin{array}{l}0.461 * * * \\
(0.0775)\end{array}$ & $\begin{array}{l}0.0979 \\
(0.249)\end{array}$ & $\begin{array}{c}-0.00283 \\
(0.129)\end{array}$ & $\begin{array}{l}0.169 * * \\
(0.0689)\end{array}$ & $\begin{array}{c}-0.873 * * * \\
(0.0482)\end{array}$ & $\begin{array}{c}-0.889 * * * \\
(0.0793)\end{array}$ & $\begin{array}{l}0.463 * * * \\
(0.0802)\end{array}$ & $\begin{array}{c}0.326 \\
(0.236)\end{array}$ & $\begin{array}{l}-0.120 \\
(0.130)\end{array}$ & $\begin{array}{l}0.171^{* *} \\
(0.0706)\end{array}$ & $\begin{array}{c}-0.864 * * * * \\
(0.0479)\end{array}$ & $\begin{array}{c}-0.805^{* * *} \\
(0.0823)\end{array}$ & $\begin{array}{l}-0.161 \\
(0.384)\end{array}$ & $\begin{array}{c}0.552 \\
(0.735)\end{array}$ & $\begin{array}{l}-1.935 * * * \\
(0.587)\end{array}$ & $\begin{array}{c}-2.100 * * * \\
(0.613)\end{array}$ & $\begin{array}{c}2.590 \\
(2.421)\end{array}$ & $\begin{array}{c}4.516^{* * * *} \\
(1.251)\end{array}$ \\
\hline Cash & $\begin{array}{c}-2.285 * * * \\
(0.0954)\end{array}$ & $\begin{array}{c}-2.750 * * * \\
(0.430)\end{array}$ & $\begin{array}{l}1.075^{* * *} \\
(0.194)\end{array}$ & $\begin{array}{c}-0.00523 \\
(0.111)\end{array}$ & $\begin{array}{c}0.537^{* * * *} \\
(0.151)\end{array}$ & $\begin{array}{c}-2.441^{* * *} \\
(0.287)\end{array}$ & $\begin{array}{c}-2.324 * * * \\
(0.0995)\end{array}$ & $\begin{array}{c}-1.126^{* * *} \\
(0.423)\end{array}$ & $\begin{array}{l}0.873^{* * *} \\
(0.214)\end{array}$ & $\begin{array}{l}-0.118 \\
(0.111)\end{array}$ & $\begin{array}{c}0.498^{* * *} \\
(0.152)\end{array}$ & $\begin{array}{c}-2.276^{* * * *} \\
(0.284)\end{array}$ & $\begin{array}{c}-1.954^{* * *} \\
(0.325)\end{array}$ & $\begin{array}{c}-4.963^{* * * *} \\
(0.660)\end{array}$ & $\begin{array}{l}1.209 * * \\
(0.515)\end{array}$ & $\begin{array}{l}0.0270 \\
(0.911)\end{array}$ & $\begin{array}{l}3.070^{* *} \\
(1.344)\end{array}$ & $\begin{array}{c}-2.151 * * * \\
(0.807)\end{array}$ \\
\hline Inverse Interest Coverag! & $\begin{array}{c}0.0161 \\
(0.0194)\end{array}$ & $\begin{array}{l}-0.0596 \\
(0.0437)\end{array}$ & $\begin{array}{l}-0.169 * * \\
(0.0753)\end{array}$ & $\begin{array}{l}0.111^{* * *} \\
(0.0422)\end{array}$ & $\begin{array}{c}-0.137 * * * \\
(0.0486)\end{array}$ & $\begin{array}{c}0.0510 \\
(0.0584)\end{array}$ & $\begin{array}{l}0.0358^{*} \\
(0.0204)\end{array}$ & $\begin{array}{l}-0.0134 \\
(0.0449)\end{array}$ & $\begin{array}{l}-0.145^{*} \\
(0.0832)\end{array}$ & $\begin{array}{l}0.102^{* *} \\
(0.0438)\end{array}$ & $\begin{array}{c}-0.144 * * * \\
(0.0480)\end{array}$ & $\begin{array}{c}0.0100 \\
(0.0669)\end{array}$ & $\begin{array}{l}-0.0708 \\
(0.0500)\end{array}$ & $\begin{array}{l}-0.0339 \\
(0.0898)\end{array}$ & $\begin{array}{c}-0.375^{* *} \\
(0.178)\end{array}$ & $\begin{array}{c}0.180 \\
(0.168)\end{array}$ & $\begin{array}{l}0.270^{*} \\
(0.154)\end{array}$ & $\begin{array}{c}0.157 \\
(0.126)\end{array}$ \\
\hline Debt Rating Dummy & $\begin{array}{l}0.344^{* * * *} \\
(0.0307)\end{array}$ & $\begin{array}{c}2.750^{* * * *} \\
(0.113)\end{array}$ & $\begin{array}{c}1.020^{* * * *} \\
(0.122)\end{array}$ & $\begin{array}{l}0.166^{* * * *} \\
(0.0612)\end{array}$ & $\begin{array}{l}-0.302^{* *} \\
(0.141)\end{array}$ & $\begin{array}{c}-0.587^{* * * *} \\
(0.0944)\end{array}$ & & & & & & & & & & & & \\
\hline Sales Growth & $\begin{array}{l}0.307 * * * \\
(0.0159)\end{array}$ & $\begin{array}{l}0.562 * * * \\
(0.0427)\end{array}$ & $\begin{array}{l}0.318^{* * *} \\
(0.0348)\end{array}$ & $\begin{array}{l}0.375 * * * \\
(0.0179)\end{array}$ & $\begin{array}{l}0.104^{* * *} \\
(0.0340)\end{array}$ & $\begin{array}{l}0.284^{* * *} \\
(0.0487)\end{array}$ & $\begin{array}{c}0.291 * * * \\
(0.0166)\end{array}$ & $\begin{array}{c}0.532 * * * \\
(0.0372)\end{array}$ & $\begin{array}{c}0.301^{* * *} \\
(0.0370)\end{array}$ & $\begin{array}{c}0.362 * * * \\
(0.0182)\end{array}$ & $\begin{array}{c}0.0979 * * * \\
(0.0342)\end{array}$ & $\begin{array}{c}0.249^{* * *} \\
(0.0515)\end{array}$ & $\begin{array}{c}0.478^{* * * *} \\
(0.0710)\end{array}$ & $\begin{array}{l}0.462^{* * *} \\
(0.0869)\end{array}$ & $\begin{array}{c}0.617 * * * \\
(0.172)\end{array}$ & $\begin{array}{c}0.849 * * * \\
(0.140)\end{array}$ & $\begin{array}{c}1.106^{* * *} \\
(0.287)\end{array}$ & $\begin{array}{c}0.546^{* * * *} \\
(0.119)\end{array}$ \\
\hline Stock Return & $\begin{array}{l}0.0223 * * \\
(0.0109)\end{array}$ & $\begin{array}{l}0.156^{* * * *} \\
(0.0205)\end{array}$ & $\begin{array}{l}0.191^{* * * *} \\
(0.0212)\end{array}$ & $\begin{array}{c}0.230^{* * * *} \\
(0.0126)\end{array}$ & $\begin{array}{c}0.135 * * * \\
(0.0143)\end{array}$ & $\begin{array}{l}-0.0649 \\
(0.0535)\end{array}$ & $\begin{array}{c}0.0327 * * * \\
(0.0110)\end{array}$ & $\begin{array}{c}0.189 * * * \\
(0.0184)\end{array}$ & $\begin{array}{l}0.191 * * * \\
(0.0222)\end{array}$ & $\begin{array}{c}0.227 * * * \\
(0.0126)\end{array}$ & $\begin{array}{l}0.133^{* * * *} \\
(0.0142)\end{array}$ & $\begin{array}{l}-0.0874 \\
(0.0623)\end{array}$ & $\begin{array}{l}0.00312 \\
(0.0395)\end{array}$ & $\begin{array}{c}0.0827 \\
(0.0607)\end{array}$ & $\begin{array}{c}0.499 * * * \\
(0.0656)\end{array}$ & $\begin{array}{l}0.595^{* * * *} \\
(0.0621)\end{array}$ & $\begin{array}{c}0.448^{* * *} \\
(0.166)\end{array}$ & $\begin{array}{c}0.0537 \\
(0.0965)\end{array}$ \\
\hline Term Spread & $\begin{array}{l}-0.0209 * * * * \\
(0.00722)\end{array}$ & $\begin{array}{c}0.0592^{* * *} \\
(0.0171)\end{array}$ & $\begin{array}{l}0.158^{* * * *} \\
(0.0267)\end{array}$ & $\begin{array}{l}0.120^{* * *} \\
(0.0158)\end{array}$ & $\begin{array}{l}0.274^{* * *} \\
(0.0291)\end{array}$ & $\begin{array}{l}0.147^{* * * *} \\
(0.0240)\end{array}$ & $\begin{array}{c}-0.0315^{* * * *} \\
(0.00864)\end{array}$ & $\begin{array}{c}-0.0654^{* *} \\
(0.0285)\end{array}$ & $\begin{array}{l}0.131^{* * *} \\
(0.0306)\end{array}$ & $\begin{array}{c}0.0950^{* * *} \\
(0.0165)\end{array}$ & $\begin{array}{l}0.274^{* * *} \\
(0.0293)\end{array}$ & $\begin{array}{l}0.102^{* * *} \\
(0.0283)\end{array}$ & $\begin{array}{l}0.0262^{*} \\
(0.0135)\end{array}$ & $\begin{array}{l}0.100^{* * *} \\
(0.0212)\end{array}$ & $\begin{array}{l}0.267 * * * \\
(0.0516)\end{array}$ & $\begin{array}{l}0.339 * * * \\
(0.0532)\end{array}$ & $\begin{array}{c}-0.170 \\
(0.163)\end{array}$ & $\begin{array}{l}-0.00699 \\
(0.0414)\end{array}$ \\
\hline Weak Credit Dummy & $\begin{array}{l}-0.100 * * * \\
(0.0160)\end{array}$ & $\begin{array}{l}-0.0364 \\
(0.0386)\end{array}$ & $\begin{array}{l}0.135 * * \\
(0.0548)\end{array}$ & $\begin{array}{c}-0.219 * * * \\
(0.0367)\end{array}$ & $\begin{array}{l}0.248^{* * *} \\
(0.0566)\end{array}$ & $\begin{array}{c}-0.0125 \\
(0.0538)\end{array}$ & $\begin{array}{c}-0.109 * * * \\
(0.0189)\end{array}$ & $\begin{array}{c}-0.310^{* * * *} \\
(0.0548)\end{array}$ & $\begin{array}{l}-0.0519 \\
(0.0618)\end{array}$ & $\begin{array}{l}-0.264 * * * \\
(0.0387)\end{array}$ & $\begin{array}{l}0.245^{* * *} \\
(0.0572)\end{array}$ & $\begin{array}{l}-0.0564 \\
(0.0631)\end{array}$ & $\begin{array}{l}-0.0505 \\
(0.0364)\end{array}$ & $\begin{array}{l}0.0758^{*} \\
(0.0430)\end{array}$ & $\begin{array}{l}0.453^{* * * *} \\
(0.113)\end{array}$ & $\begin{array}{c}0.105 \\
(0.134)\end{array}$ & $\begin{array}{c}0.157 \\
(0.352)\end{array}$ & $\begin{array}{l}-0.0160 \\
(0.0850)\end{array}$ \\
\hline Constant & $\begin{array}{c}-4.010^{* * *} \\
(0.173)\end{array}$ & $\begin{array}{c}-9.580^{* * *} \\
(0.303) \\
\end{array}$ & $\begin{array}{c}-8.823 * * * * \\
(0.688)\end{array}$ & $\begin{array}{c}-4.976 * * * \\
(0.376)\end{array}$ & $\begin{array}{c}-7.081 * * * \\
(0.977) \\
\end{array}$ & $\begin{array}{c}-9.806 * * * * \\
(1.024) \\
\end{array}$ & $\begin{array}{c}-4.140^{* * *} \\
(0.219)\end{array}$ & $\begin{array}{c}-8.246 * * * \\
(0.702) \\
\end{array}$ & $\begin{array}{l}-8.946 * * * \\
(0.506) \\
\end{array}$ & $\begin{array}{c}-4.759 * * * \\
(0.375)\end{array}$ & $\begin{array}{c}-6.976 * * * \\
(0.970)\end{array}$ & $\begin{array}{l}-8.882 * * * \\
(1.027)\end{array}$ & $\begin{array}{c}-4.563 * * * \\
(0.193) \\
\end{array}$ & $\begin{array}{c}-7.559 * * * \\
(0.322) \\
\end{array}$ & $\begin{array}{l}-7.180 * * * \\
(0.421) \\
\end{array}$ & $\begin{array}{c}-5.438^{* * *} \\
(0.465)\end{array}$ & $\begin{array}{c}-9.573 * * * \\
(1.155) \\
\end{array}$ & $\begin{array}{c}-7.464 * * * \\
(0.367)\end{array}$ \\
\hline $\begin{array}{l}\text { Observations } \\
\text { Pseudo R2 }\end{array}$ & \multicolumn{6}{|c|}{$\begin{array}{c}(0.688) \quad(0.376) \\
658,727\end{array}$} & \multicolumn{6}{|c|}{$\begin{array}{c}559,147 \\
0.062\end{array}$} & \multicolumn{6}{|c|}{$\begin{array}{c}112,512 \\
0.043\end{array}$} \\
\hline
\end{tabular}


Figure 1. Proceeds Raised from Different Types of Securities over Time

This figure presents the log of proceeds raised in real terms (constant 2000 \$US millions) by each types of security issues for each calendar month from 1971 to 2007. To smooth out the series, we plot the 11-month moving averages around a specific calendar month. The shaded areas correspond to recessions as defined by the NBER.

$\ln ($ total real proceeds, constant 2000 \$US million)

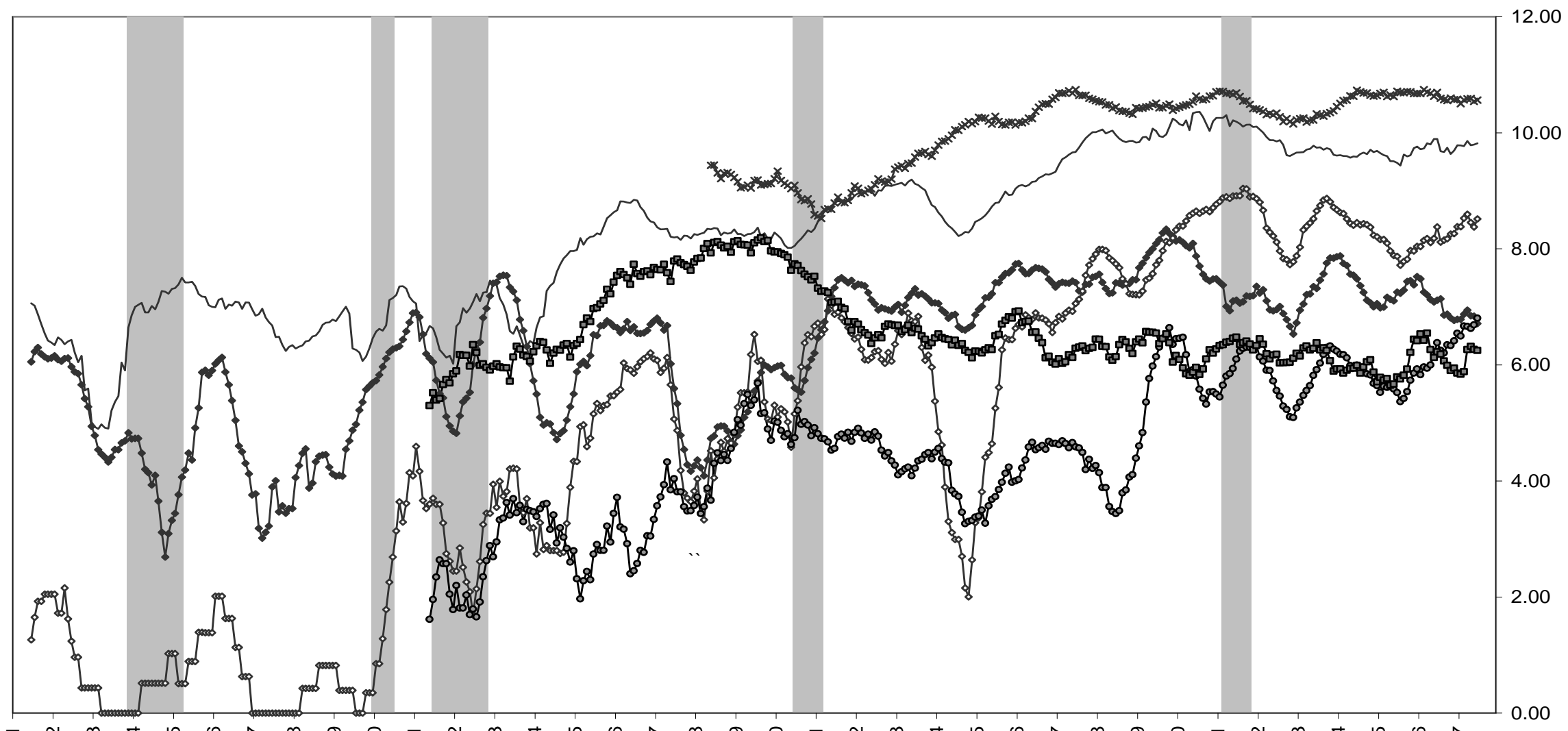

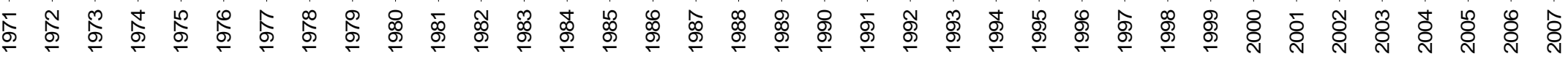

Recessions $\rightarrow$ SEOs $\multimap$ Convertibles $\longrightarrow$ Public Debt $\rightarrow$ Private Loans $\multimap$ Private Placements of Equity $\multimap-$ Private Placements of Debt 
This figure presents the log of proceeds raised in real terms (constant 2000 \$US millions) by public bonds of various quality for each calendar month from 1971 to 2007. To smooth out the series, we plot the 11-month moving averages around a specific calendar month. The shaded areas correspond to recessions as defined by the NBER.

$\ln ($ total real proceeds, constant 2000 \$US million)

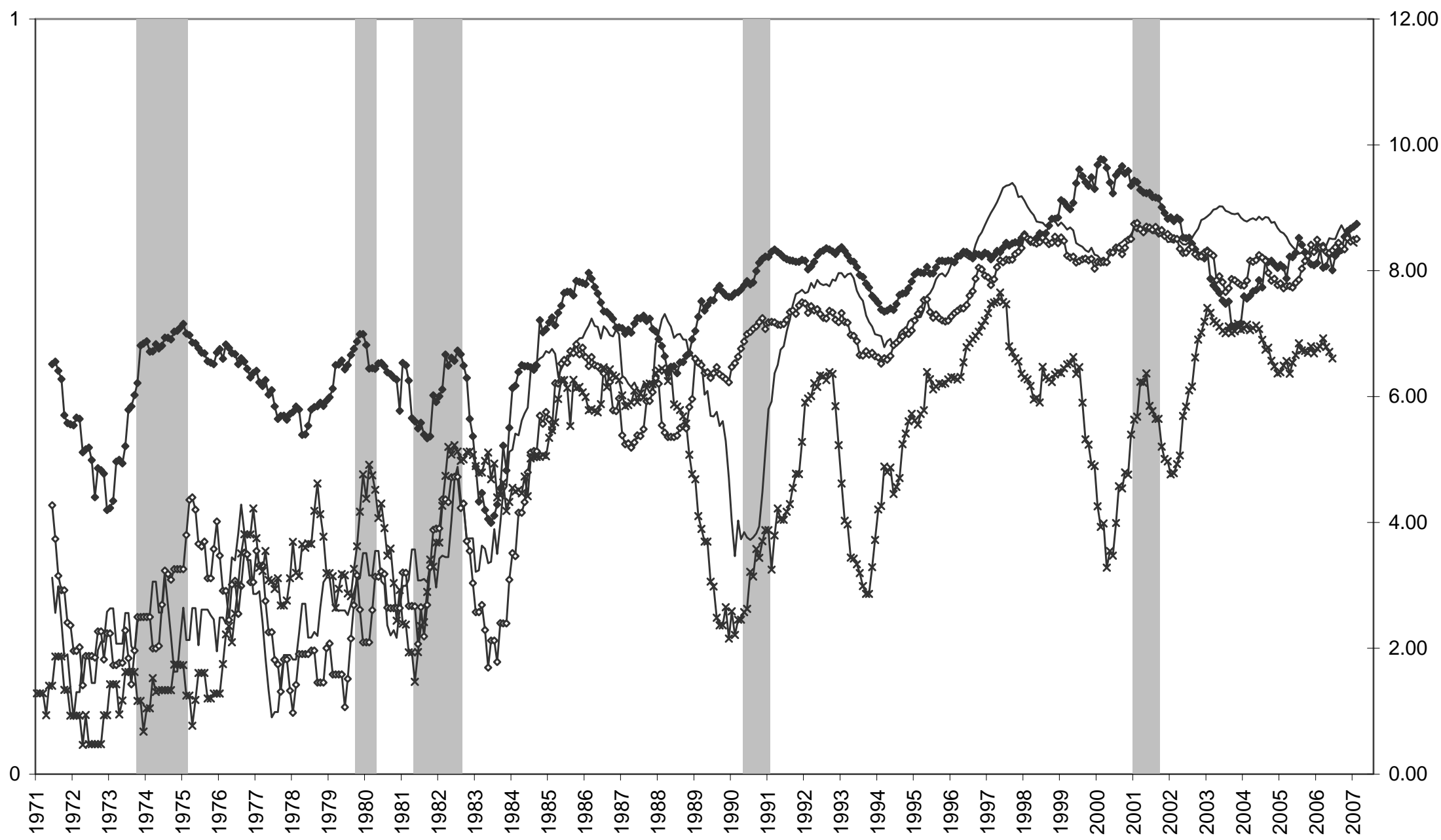

Recession $\rightarrow$ A's (A3 to Aaa) $\multimap-$ Investable B's (Baa3 to Baa1) $\longrightarrow$ Speculative B's (B3 to Ba1) $\multimap$ C's and Non Rated 
Figure 3. Credit Spread over Time

This figure presents the yields of AAA and BAA corporate bonds as well as the spread between the two for each calendar month from 1971 to 2008 . The shaded areas correspond to recessions as defined by the NBER.

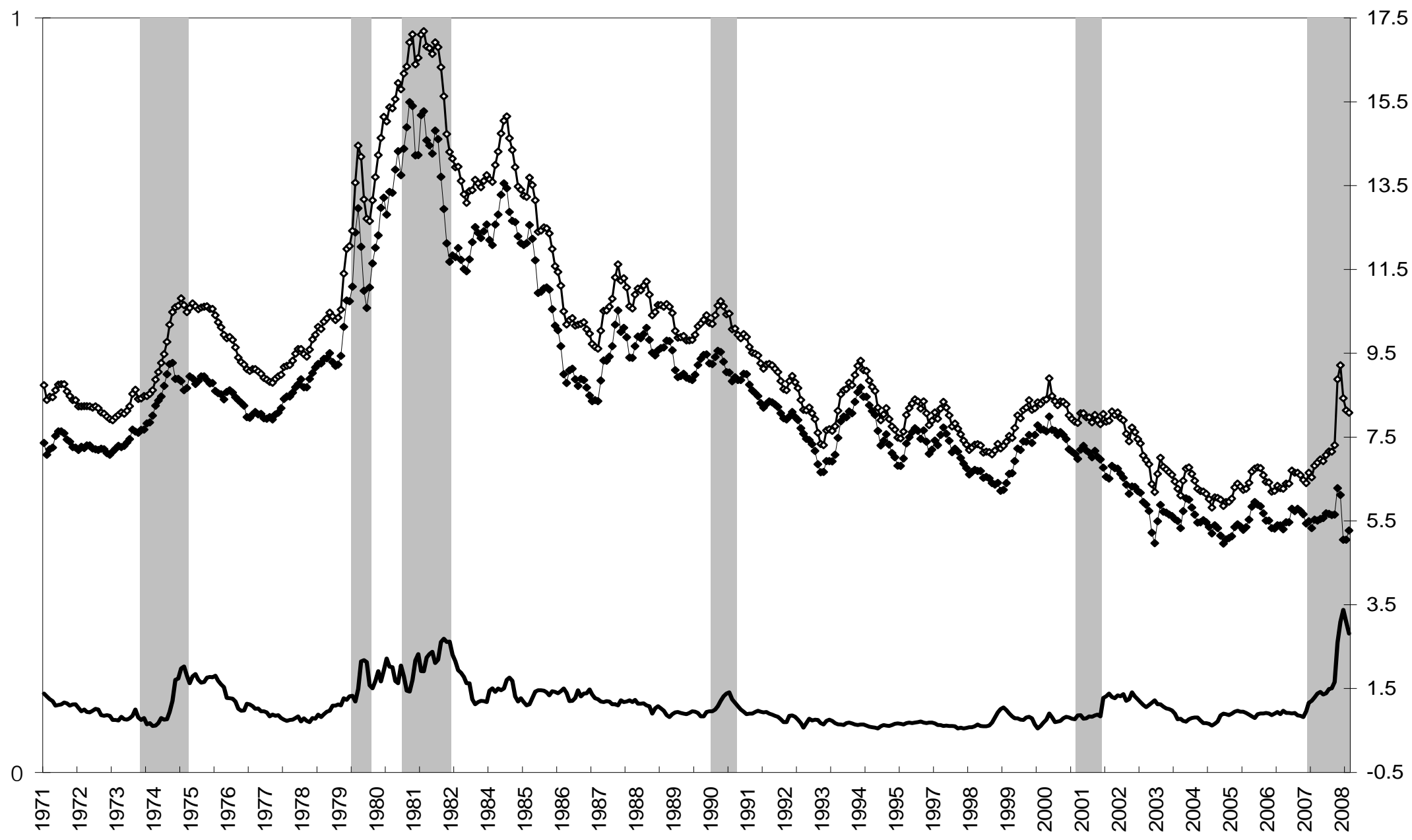

$\longrightarrow$ Recession $\longrightarrow$ AAA $\multimap$ BAA $\longrightarrow$ Credit Spread 